\title{
A Monetarist Model for Economic Stabilization*
}

\author{
by LEONALL C. ANDERSEN and KEITH M. CARLSON
}

T

1. HE MONETARIST VIEW that changes in the money stock are a primary determinant of changes in total spending, and should thereby be given major emphasis in economic stabilization programs, has been of growing interest in recent years. From the mid-1930's to the mid-1960's, monetary policy re ceived little emphasis in economic stabilization policy. Presumed failure of monetary policy during the early years of the Great Depression, along with the development and general acceptance of Keynesian economics, resulted in a main emphasis on fiscal actions-Federal Government spending and taxing programs - in economic stabilization plans. Monetary policy, insofar as it received any attention, was generally expressed in terms of market rates of interest.

Growing recognition of the importance of money and other monetary aggregates in the determination of spending, output, and prices has been fostered by the apparent failure of stabilization policy to curb the inflation of the last half of the $1960^{*}$ s. Sharply rising market interest rates were interpreted to indicate significant monetary restraint, while the Revenue and Expenditure Control Act of 1968 was considered a major move toward fiscal restraint.

Despite these policy developments, total spending continued to rise rapidly until late 1969 , and the rate of inflation accelerated. Those holding to the monetarist view were not surprised by this lack of success

"Offering helpful suggestions throughout the study were Denis Kannsky of this bank, William $P$. Yohe of Duke University and Visiting Scholar at this bank, 1969-70, and David Fand of Wayne State University. Susan Smith provided programming assistance and Christopher Babb and H. Albert Margolis advised on statistical problens. The authors thank the following for their comments on earlier drafts, without implying their endorsement of either the methods of analysis or the conclusions: F. Gerard Adams, Philip Cagan, E. Gerald Corrigan, Richard Davis, Ray Fair, Edgar Fiedler, Milton Friedman and members of the Money and Banking Workshop at the University of Chicago, Edward Gramlich, Harry G. Johnson, John Kalchbrenner, Edward Kane, Michael Keran, Allan Meltzer, Franco Modigliani, George Morrison, David Ott, Joel Popkin, Thomas Saving, Roger Spencer, Henry Wallich, Clark Warburton, Manfred Willms, and Arnold Zellner. in curbing excessive growth in total spending, largely because the money stock grew at a historically rapid rate during the four years ending in late 1968. Economic developments from 1965 through 1969 were in general agreement with the expectations of the monetarist view.

This article develops a model designed to analyze economic stabilization issues within a framework which focuses on the influence of monetary expansion on total spending. Most of the major econometric models have not assigned an important role to the money stock or to any other monetary aggregate. ${ }^{1}$ Furthermore, most econometric models contain a large number of behavioral hypotheses to be empirically estimated and integrated with each other, because they are designed to aid in understanding the determination of many economic magnitudes. By comparison, the model presented in this article is quite small. It is designed to provide information on the most likely course of movement of certain strategic economic variables in response to monetary and fiscal actions.

"Frank de Leeuw and Edward M. Gramlich, "The Federal Reserve-MIT Econometric Model," Federal Reserve BulLetin (January 1968), pp, 11-40, and "The Channels of

Monetary Policy: A Further Report on the Federal Reserve

MIT Econometric Madel," Federal Reserve Bulletin (June

1969), pp. 472-91; James S. Duesenberry Gary Fromm,

Lawrence R. Klein, and Edwin Kah (ed.), The Brookings

Qtaarterly Econometric Model of the United States (Chicago:

Rand McNally, 1965), and The Brookings Model: Some

Further Results (Chicago: Rand McNally, 1969); Michael

K. Evans and Lawrence R. Klein, The Wharton Econometric

Forecasting Model, and Enlarged Edition (Philadelphia:

University of Pennsylvania, 1968); Maurice Liebenberg,

Albert A. Hirsch, and Joel Popkin, "A Quarterly Econo" metric Model of the United States: A Progress Report," Survey of Current Business (May 1966), pp. 423-56; Daniel M. Suits, "The Economic Outlook for 1969 " in The Economic Outlook for 1969, Paper's presented to the Sixteenth Annual Conference on the Ecomomic Outlook at The University of Michigan (Amn Arbor: University of Michigan, 1969), pp. 1.26. For a discussion of the role of money in these models, see David 1. Fand, "The Monetary Theory of Nine Recent Quarterly Econonetric Models of the United States," forthcoming in the Journal of Money, Credit, and Banking, 
The model presented here is the authors' own version of how monetary and fiscal actions influence the economy. Other economists (including those of a monetarist persuasion) may prefer to develop certain aspects of the model in a different way. Two such modifications are presented in Appendix C. The model is considered open to revision, but is presented at this time with a view to stimulating others to join in quantifying relationships that are generally associated with the monetarist view.

This article is divided into five major sections. A general monetarist view of the response of spending, output, and prices to monetary and fiscal actions is summarized first. Next, the specific features of the model are discussed within a formal framework of analysis. Statistical estimates of the model's parameters are presented in the third section. The fourth section tests the performance of the model with several dynamic simulation experiments. Finally, by simulating the response of the economy to alterna tive rates of monetary expansion, an illustration is provided of how the model can be used for current stabilization analysis.

\section{General Monetarist View}

The general monetarist view is that the rate of monetary expansion is the main determinant of total spending, commonly measured by gross national product (GNP). ${ }^{2}$ Changes in total spending, in turn, influence movements in output, employment, and the general price level. A basic premise of this analysis is that the economy is basically stable and not necessarily subject to recurring periods of severe recession and inflation. Major business cycle movements that have occurred in the past are attributed primarily to large swings in the rate of growth in the money stock.

This view regarding aggregate economic relationships differs from prevailing views which consider aggressive policy actions necessary to promote stability. Monetarists generally hold that fiscal actions, in the absence of accommodative monetary actions, exert little net infuence on total spending and therefore have little influence on output and the price level. Government spending unaccompanied by accommodative monetary expansion, that is, financed by taxes or borrowing from the public, results in a crowding-ont of private expenditures with little, if any,

\footnotetext{
2General references on the monetarist view are Karl Brunner, "The Role of Money and Monetary Policy," this Review (July 1968), pp. 9-24; David I. Fand, "Some Issues in Monetary Fconomics," this Review (January 1970), pp; 10-27, and "A Monetarist Model of the Monetary Process," forthcoming in the Joumal of Finance.
}

net increase in total spending. A change in the money stock, on the other hand, exerts a strong independent influence on total spending. Monetarists conclude that actions of monetary authorities which result in changes in the money stock should be the main tool of economic stabilization. Since the economy is considered to be basically stable, and since most major business cycle movements in the past have resulted from inappropriate movements in the money stock, control of the rate of monetary expansion is the means by which economic instability can be minimized.

The theoretical heritage of the monetarist position is the quantity theory of money, ${ }^{3}$ This theory dates back to the classical economists (particularly David Ricardo) in the early 1800 's. The quantity theory in its simplest form is characterized as a relationship between the stock of money and the price level. Classical economists concentrated on the long run aspects of the quantity theory in which changes in the money stock result in changes only in nominal magnitudes, like the price level, but have no influence on real magnitudes like output and employment.

The quantity theory of money in its modern form recognizes the important influence that changes in the money stock can have on real magnitudes in the short run, while influencing only the price level in the long run. The modern quantity theory postulates that in the short run a change in the rate of growth in money is followed with a moderate lag by changes in total spending and output, while changes in the price level follow with a somewhat longer lag. ${ }^{*}$ These changes in total spending, output, and prices are in the same direction as the change in the rate of monetary expansion.

The modern quantity theory still accepts the longrun postulates of its older version. A change in the rate of monetary expansion influences only nominal magnitudes in the long run, namely, total spending (GNP) and the price level. Real magnitudes, notably

${ }^{3}$ The classic work on the quantity theory is Irving Fisher, The Purchasing Power of Money (New York: Macmillan, 1911). For an extensive review of the quantity theory literature, see Arthur W. Marget, The Theory of Prices: A Re-examination of the Central Problems of Monetary Theory (New York: Prentice-Hall, 1938), volume II, pp. 3-133.

tMany of the ideas prevalent in current monetarist doctrine can be found in the writings of Clark Warburton in the 1940 's and early 1950 's. Many of his important articles have been reprinted in his Depression, Inflation, and Monetary Policy, Selected Papers, 1945-1953 (Baltimore: The Johns Hopkins Press, 1966). See also Milton Friedman, (ed.), Studies in the Quantity Theory of Money (Chicago: University of Chicago Press, 1958), and Lloyd W. Mints, Monetary Policy in a Competitive Society (New York: McGraw-Hill, 1951). 
output and employment, are unaffected.5 Following the short-run responses to a change in the rate of monetary growth, total spending and the price level grow at rates determined by the rate of increase in money, while output moves toward and resumes a long-run growth path. Such growth in output is little influenced by the rate of monetary expansion. Instead, it is determined by growth in the economy's productive potential, which depends on growth of natural resources, capital stock, labor force, and productivity.

\section{General Form of the Model}

A summary of the model is presented in algebraic form in Exhibit I, along with a listing of variables classified as to whether they are endogenous or exogenous to the model (for a graphical illustration of the model, see Appendix B). This general form of the model summarizes its essential features, ignoring problems of dimensionality and lag length.

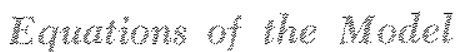

Equation (1) is the total spending equation. The change in total spending $(\Delta Y)$ is specified as a function of current and past changes in the money stock $(\Delta \mathrm{M})$ and current and past changes in high-employment Federal expenditures $(\Delta \mathrm{E})$. This general specification represents the reduced form for that class of structures which has $\Delta \mathrm{M}$ and $\Delta \mathrm{E}$ as exogenous variables. In this form the total spending equation remains uncommitted as to structure; it is potentially consistent with both Keynesian and quantity theory models. "The magnitude and significance of the estimated parameters determine whether the data conform more closely to a Keynesian or a quantity theory).

5See Milton Friedman, "The Role of Monetary Policy," American Economic Review (March 1968), pp. 1-17.

6For further discussion of the structural versus the reduced form of a model, see Michael Keran, "Monetary and Fiscal Influences on Economic Activity - The Historical Evidence," this Retiew (November 1969), pp. 5-24; Edward M. Gramlich, "The Usefulness of Monetary and Fiscal Policy as Discretionary Stabilization Tools," forthcoming in the Journal of Money; Credit and Banking; and Richard G. Davis, "How Much Does Money Matter? A Look at Some Recent Evidence," Federal Reserve Bank of New York, Monthly Reolew (June 1969), pp. 119-31.
Equation (2) specifies the change in the price level $(\Delta \mathrm{P})$ as a function of current and past demand pressures (D) and anticipated price changes $\left(\Delta P^{A}\right)$. Demand pressure is defined in equation (3) as the change in total spending minus the potential increase in output $\left(X^{F}-X\right)$. The price equation is an alternative to the standard short-run Phillips curve relation generalized to include changes in total spending and anticipated prices. ${ }^{\bar{*}}$ (See Appendix A for further development of this relationship.)

Equation (4) defines a change in total spending in terms of its components, the part associated with changes in the price level $(\Delta \mathrm{P})$ and the part associated with changes in output $(\Delta \mathrm{X}) .{ }^{8}$ With $\Delta \mathrm{Y}$ determined by equation (1), and $\Delta \mathrm{P}$ by equation (2), $\Delta \mathrm{X}$ can be derived from equation (4).

Equation (5) specifies the market rate of interest (R) as a function of current changes in the money stock $(\Delta M)$, current and past changes in output

7See Foger W, Spencer, "The Relation Between Prices and Employment: Two Views," this Review (March 1969), pp. 15-21.

8The change in the price level, $\Delta \mathrm{P}$, and the change in output $\Delta \mathrm{X}$, are defined in dollar units so that their sum is equal to the change in total spending, $\Delta \mathrm{Y}$.

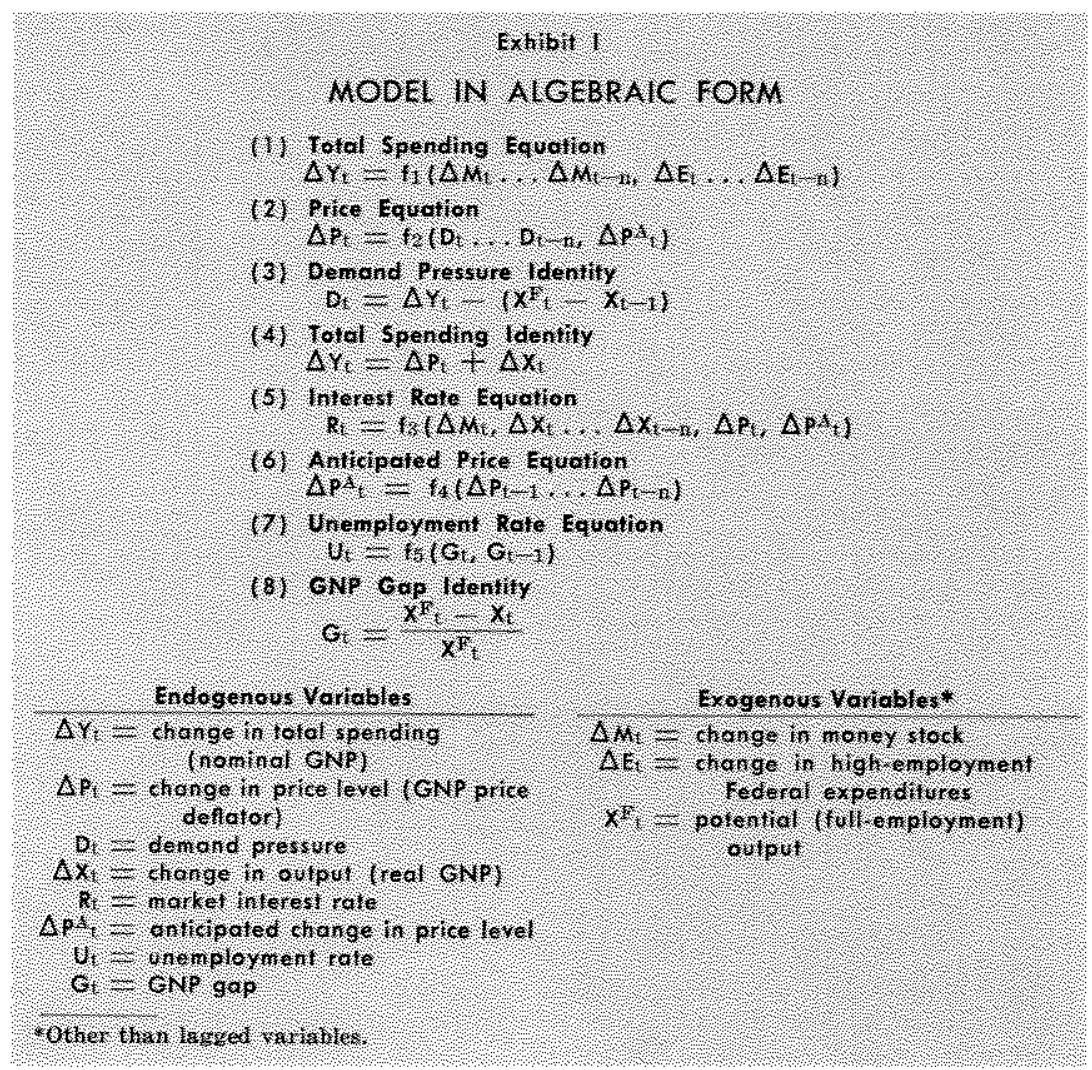


$(\Delta \mathrm{X})$, current price change $(\Delta \mathrm{P})$, and anticipated price change $\left(\Delta \mathrm{P}^{A}\right)$. The price anticipations term is included to capture the Fisher effect. The anticipated price function is defined in equation (6). Anticipated price change $\left(\Delta \mathrm{P}^{A}\right)$ in the current period is assumed to depend on past price changes $(\Delta \mathrm{P})$.

Equation (7) is the unemployment rate equation and is a transformation of the GNP gap (G), as defined in equation (8), into a measure of unemployment relative to the labor force. This transformation is based on "Okun's Law."10

\section{等}

The workings of the model are summarized by a flow diagram (Exhibit II). Only variables in the current period are shown in the diagram; lagged variables, with the exception of past changes in prices, are omitted. The relationship that determines total spending is the fundamental one among those that determine the endogenous variables of the model. Total spending is determined by monetary actions and fiscal actions (Federal spending financed by taxes or borrowing from the public), though no direct information is provided as to how such actions affect spending.

The change in total spending is combined with potential (full employment) output to provide a measure of demand pressure. Anticipated price change, which depends on past price changes, is combined with demand pressure to determine the change in the price level.

The total spending identity enables the change in output to be determined, given the change in total spending

${ }^{9}$ For a detailed study of interest rates and the Fisher effect, see William P. Yohe and Denis S. Karnosky, "Interest Rates and Price Level Changes, 1952-69," this Review (December 1969), pp. 18-38.

${ }^{10}$ Arthur M. Okun, "Potential GNP: Its Measurement and Significance," 1962 Proceeding: of the Business and Economic Statistics Section of the American Statistical Association, pp. 98-104. Okun's Law relates the GNP gap to the unemployment rate as follows:

$$
\mathrm{X}_{\mathrm{t}}-\mathrm{X}_{\mathrm{t}}=.03\left(\mathrm{U}_{\mathrm{t}}-4\right) \mathrm{X}_{\mathrm{t}}
$$

The number .03 is a productivity factor and 4 is defined as the unemployment rate consistent with full resource utilization. and the change in prices. This method of determining the change in total spending and its division between output change and price change differs from most econometric models. A standard practice in econometric model building is to determine output and prices separately, then combine them to determine total spending.

The change in output, the change in prices and in anticipated prices, along with the change in the money stock, determine market interest rates. The flow diagram shows that the market interest rate does not exercise a direct role in the model in the determination of spending, output, and prices.

To determine the unemployment rate, the change in output is first combined with potential output to determine the GNP gap relative to potential output. The GNP gap is then transformed into the unemployment rate.

\section{Bratarang}

The model has been presented in general form to show the basic linkages postulated among money, Federal expenditures, prices, and output. The purpose of the following statistical section is to estimate

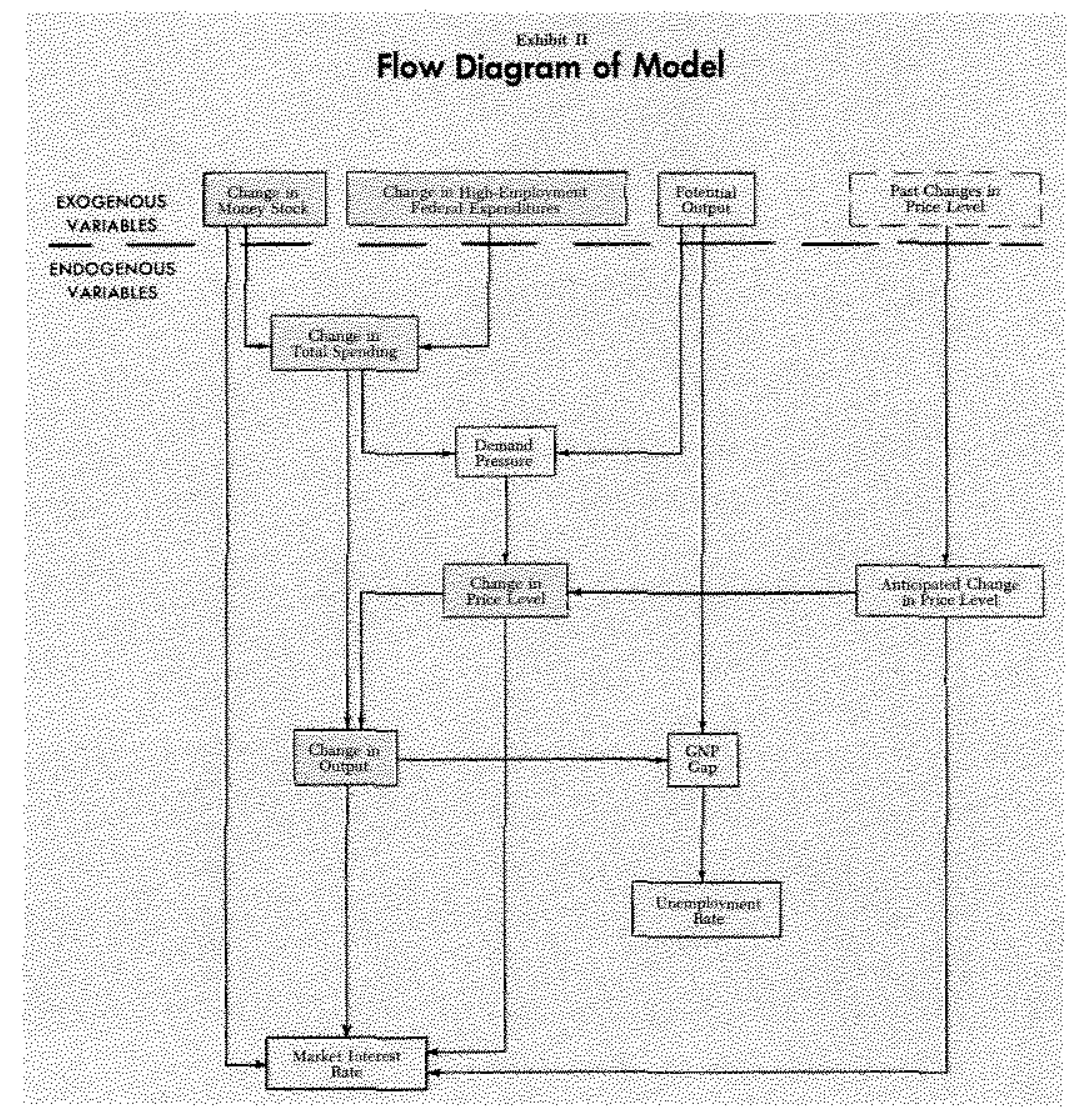


the response of output and prices to monetary and fiscal actions, not to test a hypothesized structure. The focus is on the response in the short run - periods of two or three years - but the long-run properties of the model also are examined.

\section{Estimation of the Model}

The general form of the model indicates those variables that are included in each equation. Estimation requires selection of the algebraic form of the equations and the techniques to be used in estimation.

Each of the equations of the model is estimated by ordinary least squares. Lag structures, with one exception, are estimated by the Almon lag technique. The reported relationships reflect considerable experimentation with the number of lags and the degree of the polynomial. ${ }^{11}$ The sample period starts with 1953 for the spending equation and with 1955 for all the others. The data are quarterly and, with the exception of interest rates, are seasonally adjusted.

Criteria used in the selection of the equations were minimizing the standard error of estimate and eliminating serial correlation in the estimated residuals. In addition, the signs and statistical significance of the estimated coefficients received consideration, along with the pattern of the lag distribution. Since these criteria frequently could not be satisfied simultaneously, an element of subjectivity was present in selecting the "best" equation.

\section{potol Srending}

The change in total spending is specified as a function of current and past changes in the money stock (demand deposits and currency held by the nonbank public) and in high-employment Federal expenditures (expenditures on goods and services plus transfer payments adjusted to remove the influence of variations in economic activity on unemployment benefit payments). The choice of the particular equation (Table I) is based on previous work by Andersen and Jordan. ${ }^{12}$ Implicit in this choice is the assumption that the change in the money stock is an exogenous variable. A more complete model would specify a mechanism whereby the money stock is determined by actions of the monetary authorities, the public, and the banking system.

\footnotetext{
11 For discussion of the use and interpretation of the Almon lag technique, see Keran, p. 10.

freonall $C$. Andersen and Jerry L. Fordan, "Monetary and Fiscal Actions: A Test of Their Relative Emportance in Economic Stabilization," this Review (November 1968), pp. 11-24. See also Keran, pp. 5-24.
}

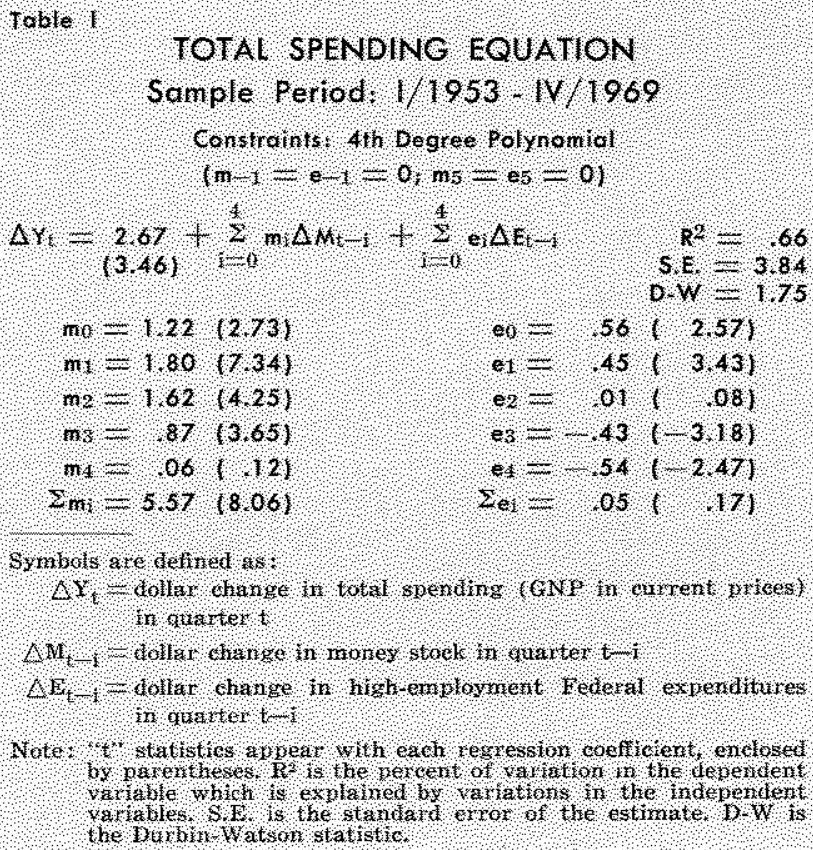

The pattern of the coefficients indicates a large and rapid influence of monetary actions on total spending relative to that of fiscal actions. ${ }^{13}$ Changes in high-employment expenditures, with the money stock held constant, first have a positive influence on total spending, but the influence becomes signifcantly negative after three quarters. Fiscal actions, unaccompanied by changes in money, have little net effect on GNP over five quarters. ${ }^{14}$ For short periods, and for extended periods in which the rate of change of Federal expenditures is either accelerating or decelerating, fiscal effects are significant. The estimated coefficients for changes in money and changes in Federal expenditures are in general agreement with the monetarist view of the response of total spending to these two variables.

The specification of the total spending equation, as shown in Table I, has been criticized as being incom-

\footnotetext{
13 Andersen and Jordan tried several measures of fiscal actions in their basic equation. The best results were obtained by using only highemployment expenditures, rather than the high-employment surplus or both high-employment expenditures and receipts, "They justify their choice by appealing to the notion that financing expenditures by borrowing from the public and taxes have essentially the same impact on total GNP. For some results that contradict those of Andersen and Jordan, see E. C. Corrigan, "The Measurement and Relative Importance of Fiscal Policy," forthcoming in Federal Reserve Bank of New York Monthly Review. It should be repeated that, a priori, specification of the total spending equation was sufficiently general as to be consistent with a number of theories of GNP determination.

1-Andersen and Jordan, p. 18, indicate that these results are consistent with a "erowding-out" theory of effects of govm ernment spending.
} 
plete in that it allegedly ignores the effects of interest

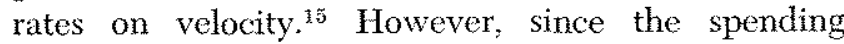
equation is a reduced form, such effects are embodied in the coefficients of money. ${ }^{16}$

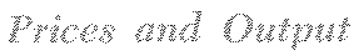

The total spending equation is the comerstone of the model, providing its monetarist character. The focus of this paper, however, is on determining the division of the change in total spending between price and output changes. Price changes are estimated as a function of (1) current and past demand pressure, and (2) anticipated price change.

Demand pressure - As a measure of demand pressure on prices, the change in total spending is related to the potential change in output (GNP in constant prices). ${ }^{17}$ These two variables, when combined, provide a measure of the economy's demand for goods and services relative to its capacity to supply goods and services. The change in prices is specified as a positively related linear function of this measure of demand pressure (see Appendix A).

Demand pressure, $\mathrm{D}_{t}$, is defined as:

$$
\mathrm{D}_{\mathrm{t}}=\Delta \mathrm{Y}_{\mathrm{t}}-\left(\mathrm{X}_{\mathrm{t}}-\mathrm{X}_{\mathrm{t}-1}\right),
$$

where $\Delta \mathrm{Y}_{\mathrm{t}}$ is the change in total spending in quarter $t ; X^{*}$ is potential (full employment) GNP in 1958 prices in quarter $t$; and $X_{t-1}$ is real GNP in the previous quarter. ${ }^{18}$ Given the GNP gap, defined as $X^{F_{t}-X_{t-1}}$, the larger is the change in total spending

\footnotetext{
15See Paul S. Anderson, "Monetary Velocity in Empirical Analysis," in Controlling Monetary Aggregates, Proceedings of the Monetary Conference held on Nantucket Istand (June 1969) pp. 37-51, and the discussion of that paper by Leonall C. Andersen, pp. 52-55. See also Henry A. Latané, "A Note on Monetary Policy, Interest Rates and Ineome Velocity," Southern Economic Journal (January 1970), pp. 328-30.

16See A. A. Walters, "Monetary Multipliers in the U, K.: 1880-1962," Oxford Economic Papers (November 1966):

17This measure was apparently frst used by Ray Fair of Princeton University. See his "The Determination of Aggregate Price Changes," forthcoming in the Joutnal of Political Economy. For a similar specification of a price equation, see Milton Friedman, "A Theoretical Framework for Monetary Analysis," also forthcoming in the Journal of Political Economy. See also a paper by William Considine of Stanford University, "Public Policy and the Current Inflation," prepared as a part of a stmmer intern program at the U.S. Treastry Department (September 5, 1969).

$18 T h e$ series on potential output is based on that used by the Council of Economic Advisers. Currently, potential output is estimated to be rising at a 4.3 per cent annual rate. For alternative estimates of potential output, see Fair, "The Determination of Aggregate Price Changes."
}

$\left(\Delta Y_{t}\right)$, the greater is the spillover into higher prices. Given $\Delta \mathrm{Y}_{t}$, the larger is $\mathrm{X}_{\mathrm{t}}-\mathrm{X}_{\mathrm{i}-\mathrm{t}}$, the greater is the expansion of output and the less the spillover into higher prices.

In addition to current values, past values of the demend pressure variable are included in the price equation. The purpose of including past values is to allow for lags in the determination of prices in response to changing demand. Furthermore, the impact of changing demand through changing input prices and costs of production is given a chance to operate by including lagged values for the demand pressure variable.

Anticipated Price Change - The other independent variable included in the price equation is a measure of anticipated price change $\left(\Delta \mathrm{P}_{t}{ }_{t}\right)$. The purpose of including this variable as a factor influencing current changes in the price level is to allow anticipations of future price movements to influence the decisions of market participants. Since such a variable is not

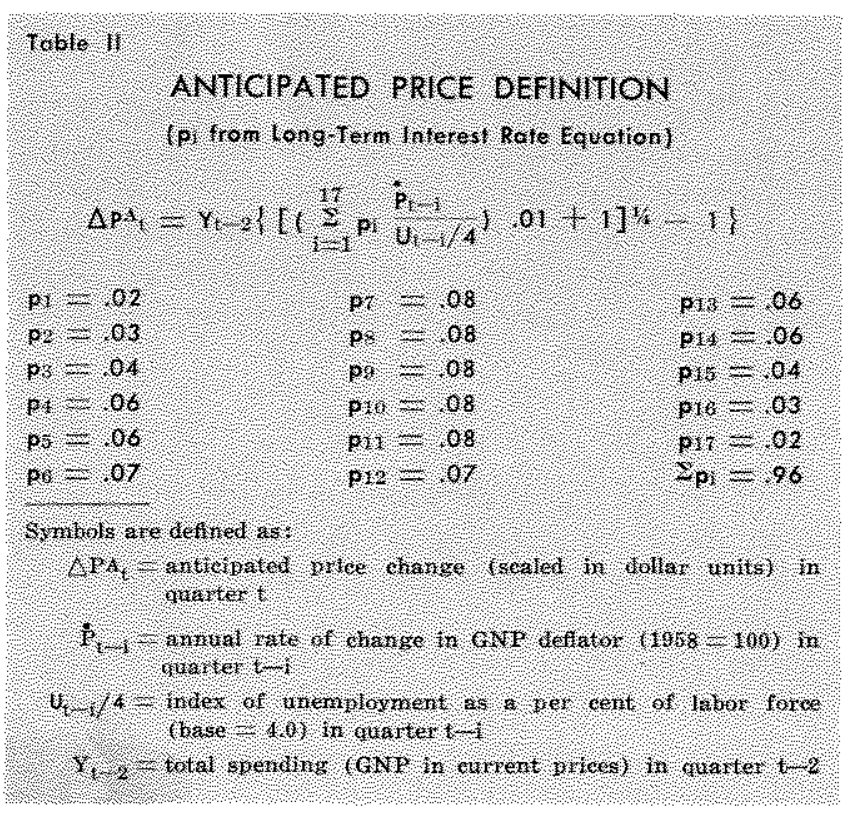

observable, it has to be constructed. This is accomplished by assuming that anticipations about future price changes are formed on the basis of past price experience.

The measure of price anticipations used in this study is a by-product of estimating long-term market interest rates. ${ }^{19}$ Yohe and Karnosky showed that long-term market interest rates respond to price anticipations of borrowers and lenders, since commit-

19 For other ways of handling expectations, see Appendix $C$ on alternative price equations. 
ments to borrow and lend funds require an assessment of anticipated changes in the price level for the period of the loan. The problem consists of isolating this price effect on market interest rates from factors influencing the real rate.

In the process of constructing a measure of anticipated price change, past changes in prices are adjusted by a summary measure of current economic conditions. Since price changes tend to lag changes in total spending the degree of resource utilization as measured by the unemployment rate is used as a leading indicator of future price movements. ${ }^{20}$ For example, if unemployment is rising relative to the labor force, decision-making economic units would tend to discount current inflation in forming anticipations about future price movements. Reflecting this consideration, the price change in each quarter is divided by an index of the unemployment rate applicable to that quarter. Thus the measure of price anticipations would be less for a given inflation rate accompanied by high or rising unemployment than when unemployment is low or falling.

The specific definition of price anticipations is shown in Table II. The weights and the length of the lag period were obtained from the estimated longterm interest rate equation. ${ }^{21}$

Estimated price equation-The estimated price equation is shown in Table III, where $\Delta \mathrm{P}_{\mathrm{t}}$ is defined as the dollar change in total spending due to price changes in quarter $t$. The influence on prices of the demand pressure variable, $D_{-i}$, is significant and positive for five quarters but very small thereafter. ${ }^{22}$ The pattern of influence is one of steady decay, with 70 per cent of the total effect of demand pressure taking place in the first three quarters and 95 per cent in the first five quarters.

Anticipated price change, represented by $\Delta \mathrm{P}^{\mathrm{A}}{ }_{\text {, }}$, is a significant determinant of current price change.

\footnotetext{
20For purposes of exposition the unemployment rate was not included in the definition of anticipated price change in Exhibits $I$ and $I I$.

21 The price expectations variable as shown in Table II is scaled in dollar mits. This transformation is made because prices are estimated as the dollar change in total spending due to price changes.

2. When the price equation is estimated with the components of $D_{t-1}$ separated, the coefficients for the $\Delta Y_{\text {: }}$ portion are not statistically significant at the five per cent level, implying that the gap portion, $\left(X^{F_{t}} \cdot X_{t-1}\right)$, explains most of the changes in $\Delta \mathrm{P}_{\mathrm{f}}$. However, there may be collinearity problems which influence the estimated coefficients. Furthermore, the $D_{t-\mathrm{s}}$ form is nsed because, theoretically, it is a measure of excess demand (see Appendix A).
}

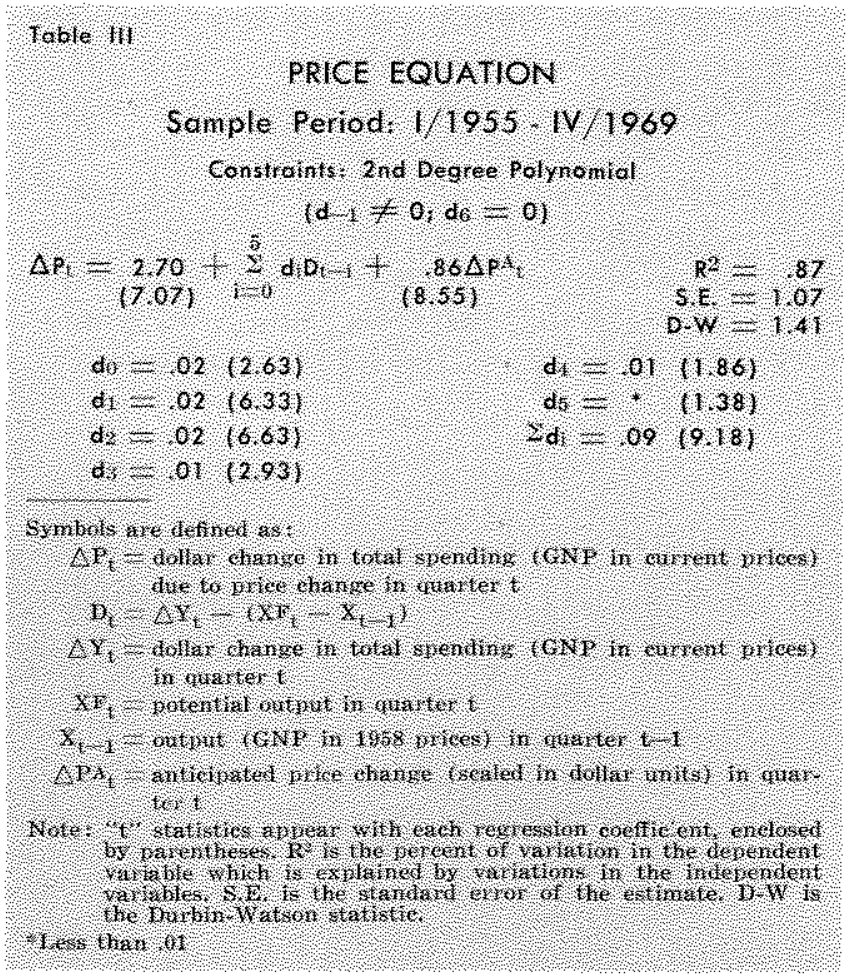

Though significant, the measure of the impact of this variable should not be taken too literally, because its construction indicates that it cannot really be viewed independently of the demand pressure variable. ${ }^{23}$ The infuence of these two variables should perhaps be viewed in combination, rather than as independent and separate influences. ${ }^{24}$

Determination of output-Given $\Delta \mathrm{Y}_{\mathrm{t}}$ as determined by the total spending equation, and $\Delta \mathrm{P}_{\mathrm{t}}$ from the price equation, the dollar change in total spending due to output changes, defined as $\Delta \mathrm{X}_{t}$, can be derived from the following identity:

$$
\Delta \mathrm{Y}_{\mathrm{t}}=\Delta \mathrm{P}_{\mathrm{t}}+\Delta \mathrm{X}_{\mathrm{t}}+\left(\mathrm{P}_{\mathrm{t}}-\mathrm{P}_{\mathrm{t}-\mathrm{1}}\right)\left(\mathrm{X}_{\mathrm{t}}-\mathrm{X}_{\mathrm{t}-1}\right) .
$$

The cross product term is assumed equal to zero. ${ }^{25}$ Thus,

$$
\Delta X_{\mathrm{t}}=\Delta \mathrm{Y}_{\mathrm{t}}-\Delta \mathrm{P}_{\mathrm{t}}
$$

225 From the standpoint of the model as a mit, price anticipations are important only in determining the division of total spending between prices and output, not the level (or change) of spending itself. To allow for the possible direct influence of price expectations on total spending, the spending equation was estimated with the price anticipations variable. The coefficient of the price anticipations variable was not significant for this specification.

24 There is, however, sone evidence that the price anticipations varable may be interpreted as an independent and separate influence. When the price equation is estimated without $\triangle \mathrm{P}^{\mathrm{A}}$, the sum of the coefficients on $\mathrm{D}_{\mathrm{i}-\mathrm{i}}$ is only slightly more than shown in Table III and the standard error is increased considerably.

25The value of this cross-product term was calculated from 1953 to the present and provides ample justification for 


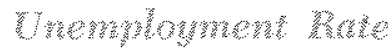

The unemployment rate plays a role in the model, representing the means by which past prices are adjusted to take into account varying economic conditions in the formation of anticipated price changes. To estimate the unemployment rate, the unemployment rate is regressed on current and lagged values of the GNP gap, expressed as a per cent of potential GNP. This equation is estimated by unconstrained ordinary least squares, and is shown in Table IV.

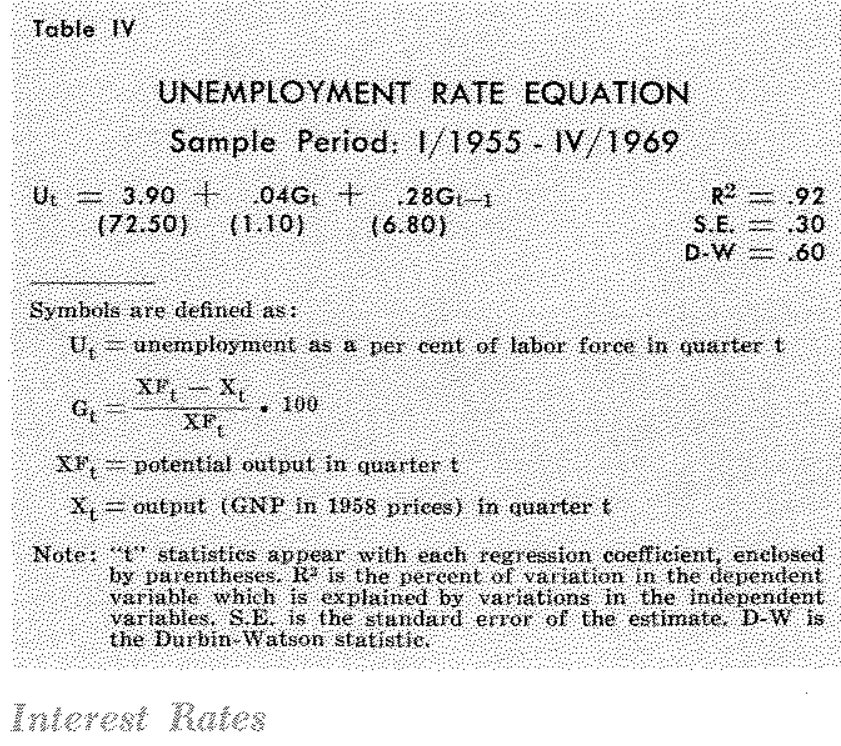

S,mols oro defrned or:

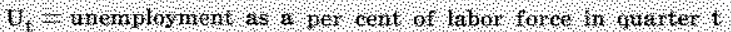

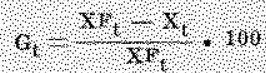

Xit tootertul outout in quarter:

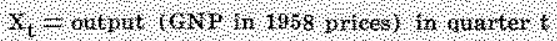

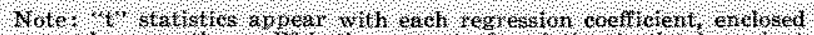

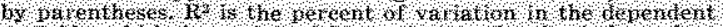

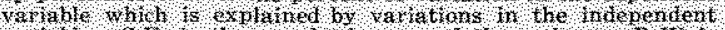

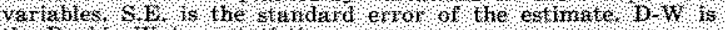
the Bubin Watson statistie.

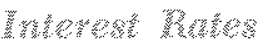

Interest rates do not function explicitly in the model as a part of a transmission mechanism ruming from changes in the money stock to output and prices. The estimated long-term interest rate equation plays a vital role in the model, however, providing the information to calculate the measure of price anticipations.

Market interest rates are specified to depend on current and past rates of change of output $(\dot{x})$, the current rate of change in the money stock ( $\mathrm{M}$ ), and current and past rates of change in prices $(\dot{\mathrm{P}}) \mathrm{ad}-$ justed by an index of the unemployment rate. This specification draws on Sargent's work, which was explored further by Yohe and Karnosky. ${ }^{26}$

the assumption that it be equated to zero for purposes of the model here. Also note that $\Delta P_{E}$ is defined in dollar units, that is, as $\left(P_{t}-P_{t-1}\right) X_{t-1}$, not $\left(P_{t}-P_{t-1}\right) . \Delta X_{t}$ is defined analogously.

20Thomas Sargent, "Commodity Price Expectations and the Interest Rate," Ouarterly Joumal of Economics (Febriary 1969), pp. 127.40, and Yohe and Karnosky, pp. 31-34, 38. The estimated interest rate equations also contain a dumny variable ( 0 for $1955+60$ and 1 for 1961-69). The significance of this dumny variable indicates a shift of structure within the sample period. Questions can be raised rables

\section{IONG TERM INTEREST RATE EQUATION}

Sample Period. $1 / 1955$ V 1969

Constraints: 2nd Degree Polynomiti

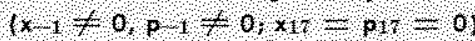

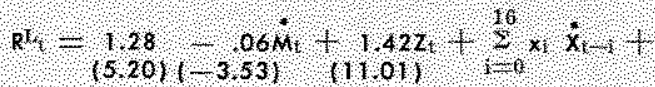

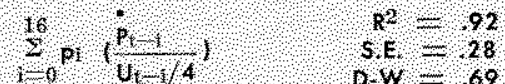

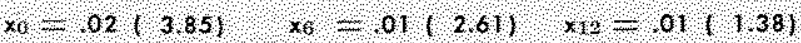

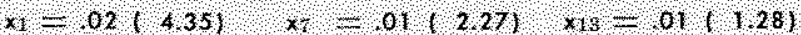

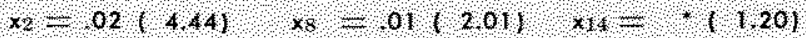

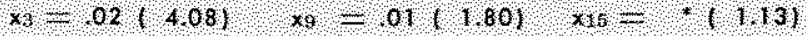

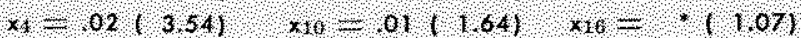

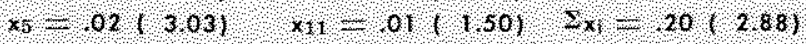

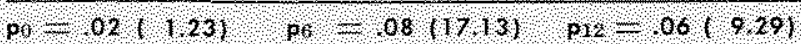

$\mathrm{pl}(-03(3.05) \mathrm{pF}=08(14.49) \quad \mathrm{plB}=06(8.89)$

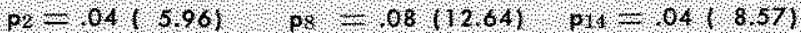

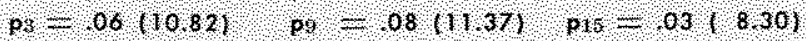

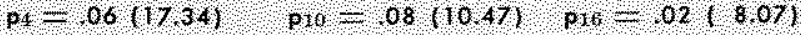

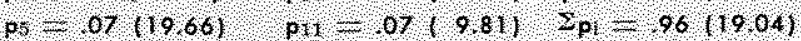

Sunbls ore definet as

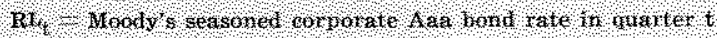

1), thrual hate of changee in mores stolk in quartert

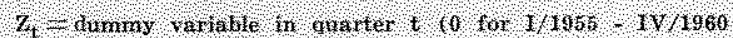
and I for $1 / 1961$ - TV/1969

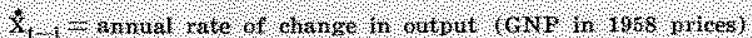
$110 \mathrm{arater}$ -

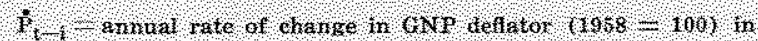
Tharter $t$

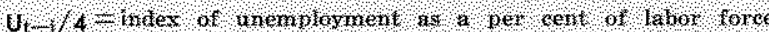
Gase $-1,0$, in , a a ter t t

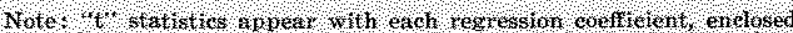
y parrentheses, $\mathrm{R}^{3}$ is the percent of vatiation in the dependen varishle which is explained hy pariations in the indepentent variables. SAL is the taridarl etror of the estimate. DW is the Durbin Watson statistic.

toes than 01

Long-term interest rate - The long-term market rate $\left(\mathrm{R}^{\mathrm{L}_{i}}\right)$ is measured by the rate on seasoned corporate Aaa bonds. Changes in output and prices (adjusted for unemployment) lagged for 17 quarters provide the most satisfactory results. The estimated equation for the long-term rate is shown in Table V.

The results reflect, in a general way, the view stressed by monetarists that a change in the rate of monetary expansion infuences market interest rates in three stages. ${ }^{2 \tau}$ First, the liquidity effect of an increase in the rate of change of the money stock

about this procedure, but it is felt that a price expectations variable should not be constructed on the basis of a sample period containing only an expansion like 1961-69.

Including the dumny variable leaves unexplained that factor (or factors) which changed the relationship, but it does provide a way of estimating a set of coefficients on prices that is based on a sample period reflecting varying economic circumstances.

${ }_{27}$ See Friedman, "The Role of Monetary Policy," p. 6. 
on market interest rates is negative. Second, an increase in the rate of monetary expansion influences the rate of change in output, which in turn has a positive influence on market interest rates. Finally, an increase in money growth influences the rate of change in prices, which has a positive effect on market interest rates.

Short-term interest rate - The short-term interest rate $\left(\mathrm{R}_{\mathrm{r}}^{\mathrm{s}}\right)$ which is estimated is the four- to six-month commercial paper rate. The equation is shown' in Table VI. Price changes are found to enter signifcantly for a shorter lag period than in the long-term rate equation. Also, the short-term rate, as measured by the four- to six-month commercial paper rate, is much more sensitive to changes in output and the money stock than is the long-term rate as measured by the rate on seasoned corporate Aaa bonds.

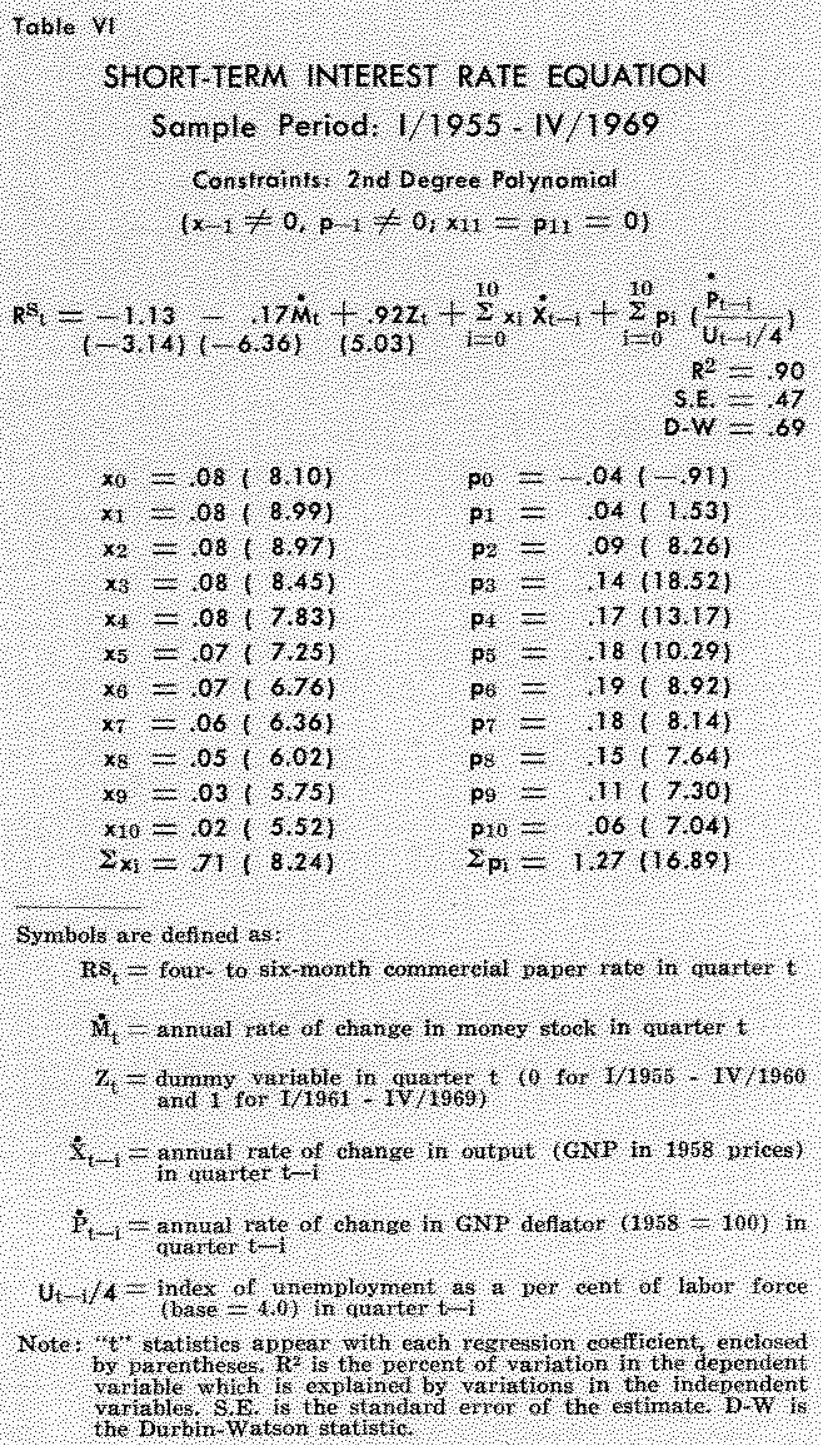

Symbols are ceftred as,

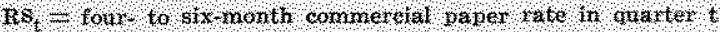

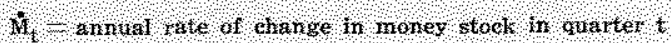

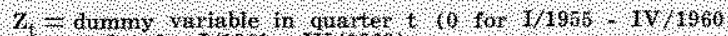

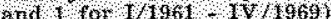

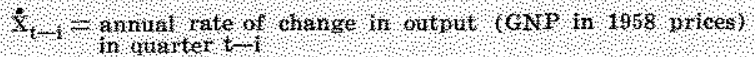

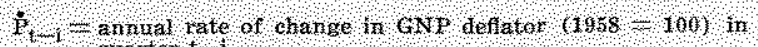
guater $t-1$

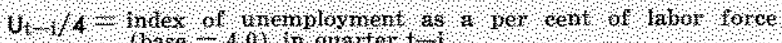

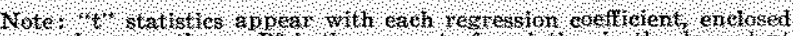
by parentheses, $\mathrm{C}^{2}$ is the percent of paration in the dependent sariable wheh is explained by varations in the independent

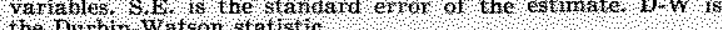
t7e Durbin-Watson statistice:

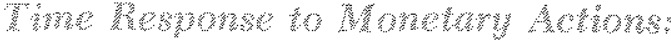

\section{A simangy}

The pattern of the coefficients in the equations provides information about the time response of total spending, output, and prices to monetary and fiscal actions. The equations indicate that monetary actions generally affect total spending with a two- to threequarter lag. A change in the rate of growth of total spending is accompanied by a simultaneous change in the rate of growth of output, and it is not until three quarters later that the response of prices to a change in demand pressure builds to 70 per cent of the total. The response of prices to a change in total spending is yet slower when there are anticipations of a high rate of inflation.

The spending equation (Table I) indicates that about half of the total response to a change in monetary growth occurs in the first two quarters, and about 80 per cent in the first three quarters.

The pattern of coefficients in the price equation (Table III) indicates that the effect of a change in total spending is reflected first in output and later in prices. Operating through the demand pressure variable, about a fourth of the response of prices to a change in total spending is in the first quarter, which is about two quarters after the change in monetary actions. Over 70 per cent of the price response is in the first three quarters, and 95 per cent in the first five quarters. The response of the price level to changes in total spending is also influenced by anticipated prices. The greater the anticipated rise in prices, the longer delayed is the response of the price level to a decline in the rate of change in total spending.

\section{Tests of the Model's Performance}

The equations of the model are to be viewed as a unit, and the specification of the model is such that given the change in money $(\Delta \mathrm{M})$, and the change in high-employment expenditures $(\Delta \mathrm{E})$, the model can be solved in the following sequence: for the change in total spending $(\Delta Y)$, the change in the price level $(\Delta P)$, the change in real output $(\Delta X)$, the unemployment rate ( $\mathrm{U}$ ), and the long- and shortterm interest rates $\left(R^{L}\right.$ and $\left.R^{s}\right)$.

The explanatory power of each of the equations shown in Tables I-VI may be acceptable by conventional standards, but this provides no guarantee that the model will perform satisfactorily as a unit. There are interdependencies in the model that have to be taken into account when evaluating the complete 
model. Of interest in evaluating the model as a unit is the implied pattern for the endogenous variables when only an initial set of lagged endogenous variables and the time paths of the exogenous policy variables (money stock and high-employment Federal expenditures) are assumed known. To conduct such a test, several dynamic simulation experiments were performed. These simulations take the form of ex post dynamic simulations and an ex ante dynamic simulation. ${ }^{28}$

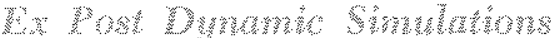

An ex post dynamic simulation is confined to the sample period from which the estimated relationships are derived. Actual values for all current and lagged exogenous variables are used, but only initial actual values for the lagged endogenous variables are used. The model generates solution values for the endogenous variables in the first simulation period, which are then used to generate solution values for the second period, and so on for each succeeding period. ${ }^{29}$ A comparison of these calculated time paths for the endogenous variables with their actual time paths enables one to formulate some judgment as to how well the model performs as an interdependent unit in tracking the movements of certain strategic economic variables.

Ex post dynamic simulations were conducted for several subperiods within the sample period (1955. 69). The results for the entire sample period are summarized in Chart I on the next page. When simulations are conducted for subperiods within the 1955-69 period, the pattern of movement as shown for the whole period simulation tends to hold, but the levels are closer to the actual values at the beginning of each subperiod.

Chart 1 indicates that the model tends to track the movement of the endogenous vari-

\footnotetext{
${ }^{2} \overline{5}$ For a discussion of the different ways of assessing the tracking ability of econometric models, see Carl F. Christ, "Econometric Models of the Financial Sector," forthcoming in the Joumal of Money, Credit, and Banking. For a dis" cussion of simulation procedures and results with an income-expenditure model, see Evans and Klein, pp. $50-69$.

${ }^{29}$ See de Leeuw and Gramlich, "The Channels of Monetary Policy ...." p. 485 .
}

ables quite well during the $1955-69$ period. Since criteria for judging the performance of the model in such a simulation have not been developed, any conclusions are necessarily subjective. ${ }^{30}$ The tendency for the model to avoid diverging sharply from the actual path for extended periods is an especially important feature. Such a feature provides some basis for trusting the tracking ability of the model over several quarters, even if on a quarter-by-quarter basis it may appear to be off the mark.

To gain additional information about the predictive performance of the model, a comparison is made with an ex post simulation from another model. Results of an ex post simulation for 1963 and 1964 have been published for the Wharton model. The results for the model are compared with those of the Wharton model in Table VII.

The period 1963-64 includes the 1964 tax cut, which, according to the Wharton model, is considered an important factor influencing economic developments in 1964. However, the St. Louis model, which does not emphasize such fiscal actions, did about as well, on average, for the years 1963 and 1964 (see Table VII). The main difference to be remembered in evaluating these simulations is that the St. Louis model contains three primary exogenous variables, while the Wharton model contains forty-three.

\footnotetext{
30See Robert H. Rasche and Harold T, Shapiro, "The F.R.B. - M.I.T. Econometric Model: Its Special Features," American Economic Review, Papers and Proceedings (May 1968), p. 142.
}

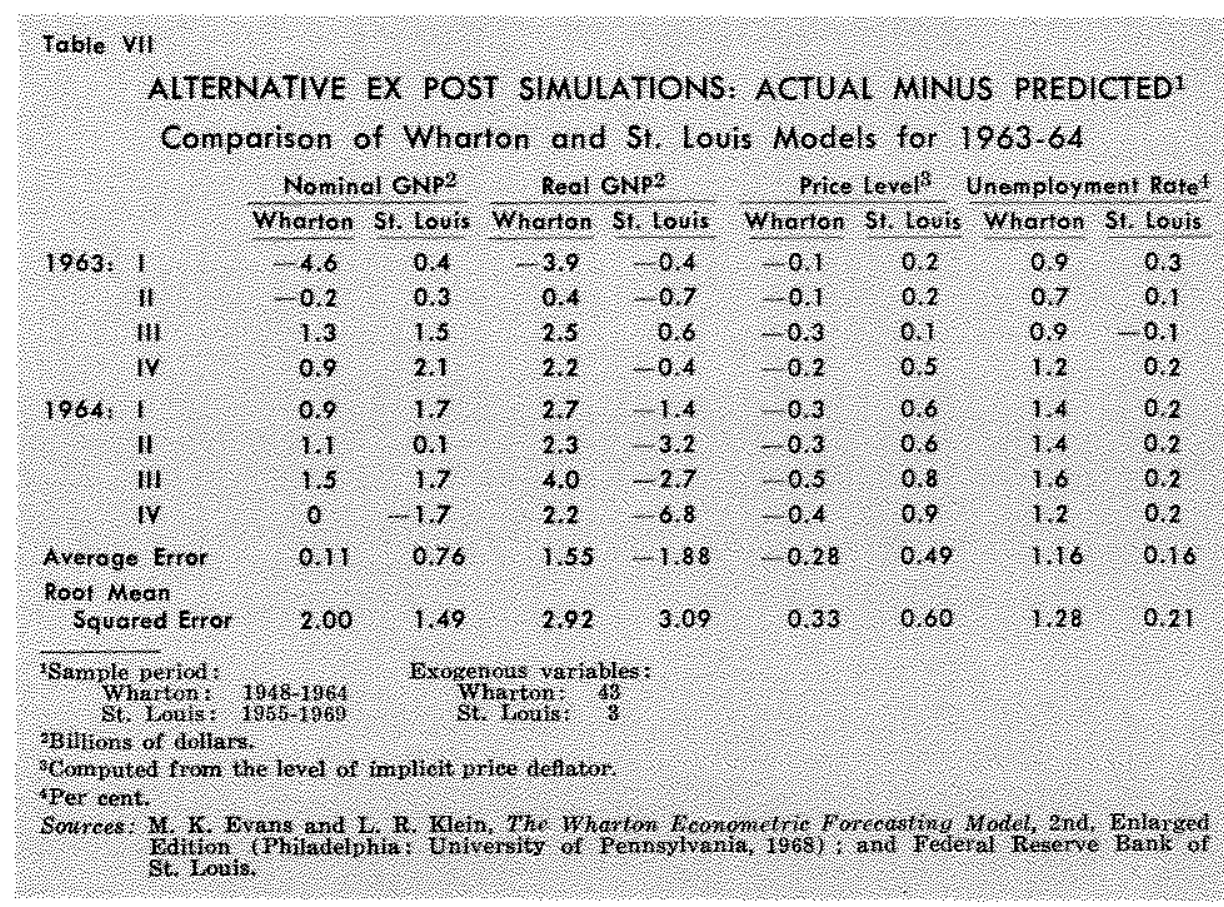




\section{Results of Ex Post Dynamic Simulation}
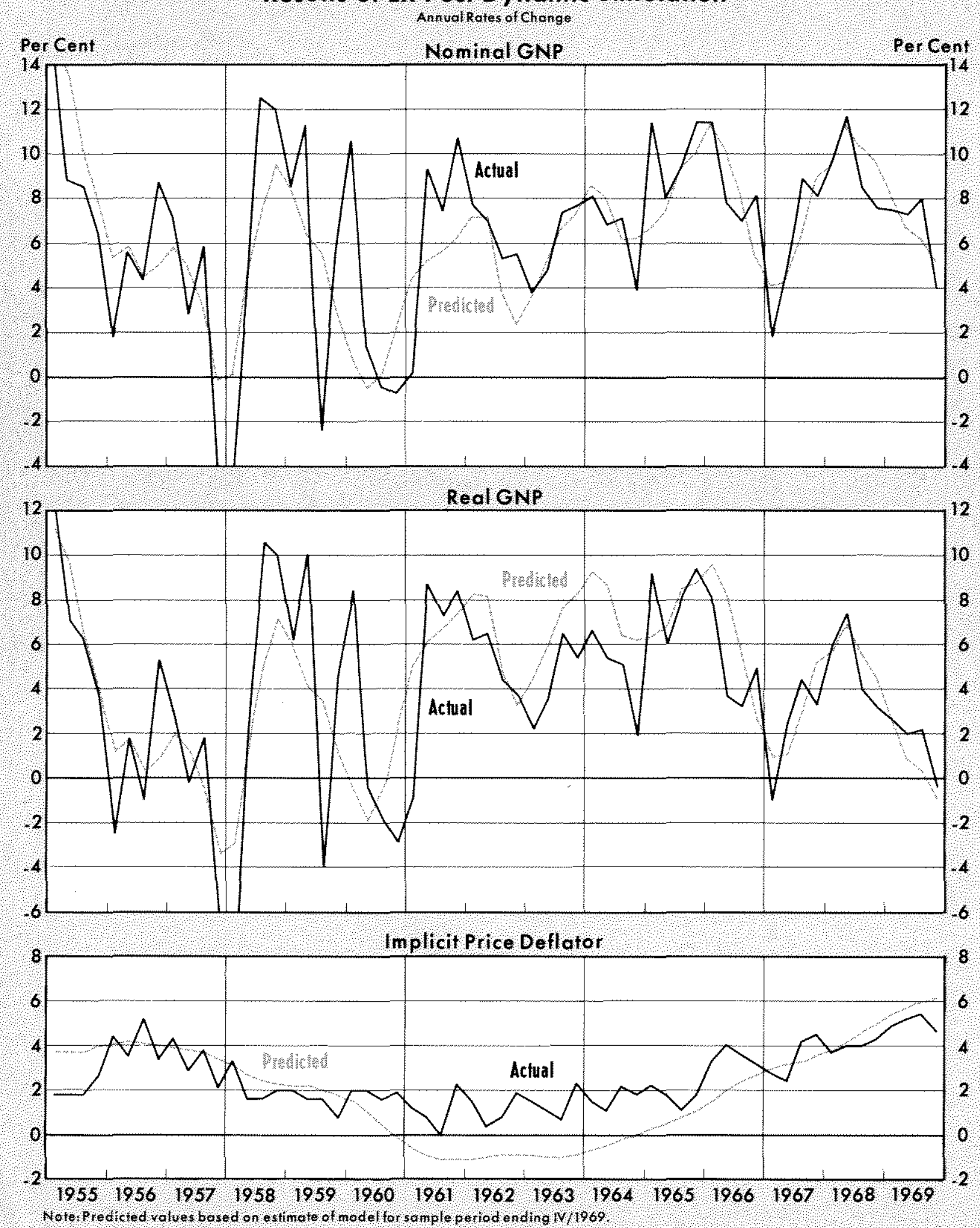
The comparison is not meant to imply that the St. Louis model is superior. Rather, the suggestion is offered that a small model constructed within a monetarist framework may yield as much information about the key aggregates as a large structural model. In summary, small monetarist models may be useful as a guide in the formulation of stabilization policy.

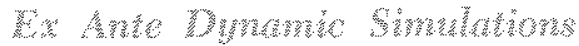

An $e x$ ante dynamic simulation is like an ex post dynamic simulation, except that it extends beyond the sample period. To conduct such a simulation for this model, it was necessary to re-estimate the model for a subperiod within the full sample period. All equations of the model were re-estimated with data through 1967. The period of the ex ante dynamic simulation is 1968 and 1969. The results are summarized in Chart II and in Tables VIII and IX.

The success of the ex ante dynamic simulation can be assessed by comparing it with the tracking record of the ex post simulation for the same period. A comparison of the errors associated with the ex ante simulation with those of the ex post simulation (where the errors in both cases are computed with reference to actual values) suggests that any structural shifts that occurred in the 1968-69 period were not of such a magnitude that the ex ante tracking ability of the model was significantly different from that of ex post simulation.

Any conclusions about the tracking ability of the model are necessarily tentative, because they are based on only one ex ante dynamic simulation experiment. Nevertheless, these results provide a tentative basis for confidence in the tracking ability of the model in es-

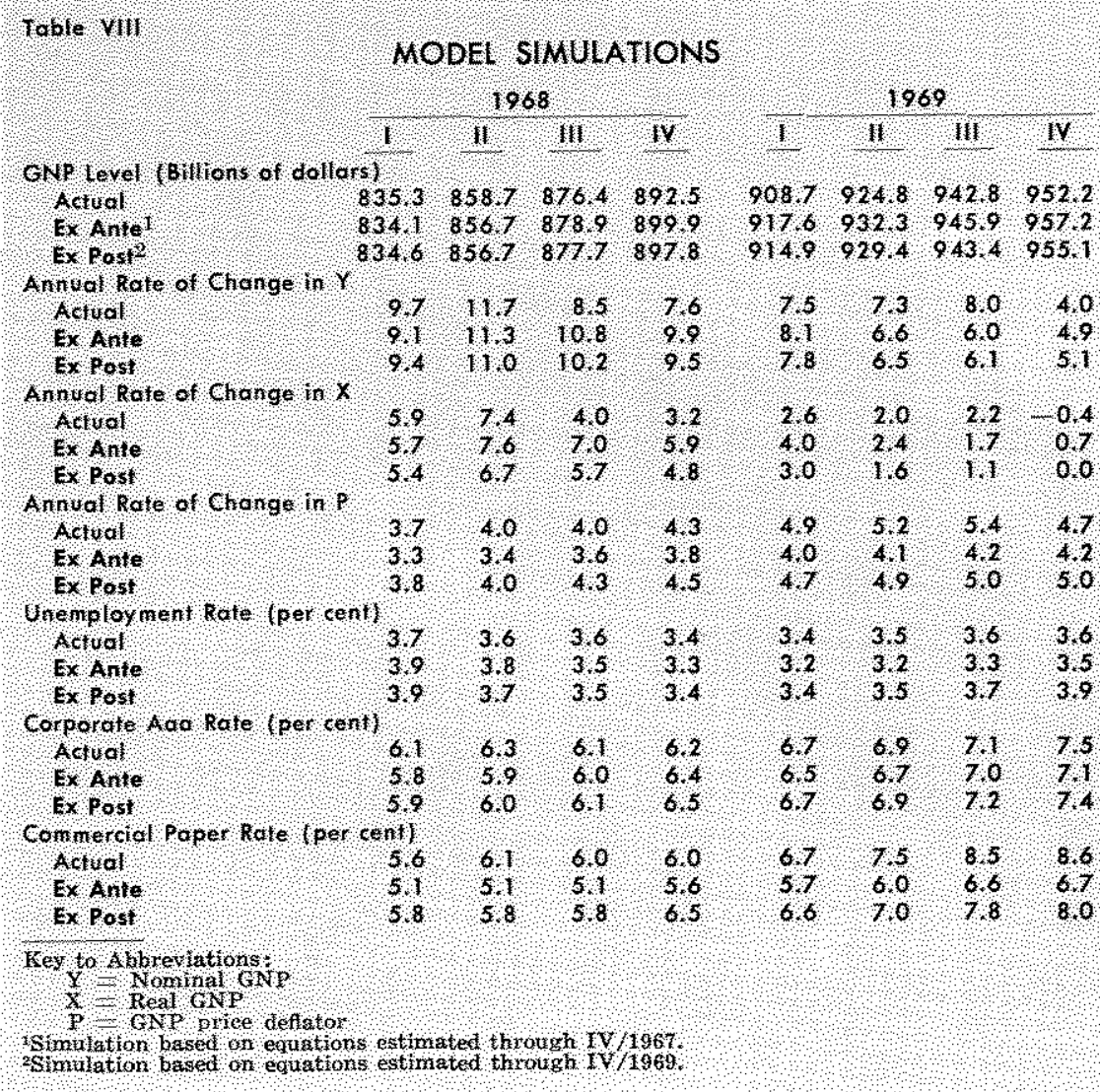
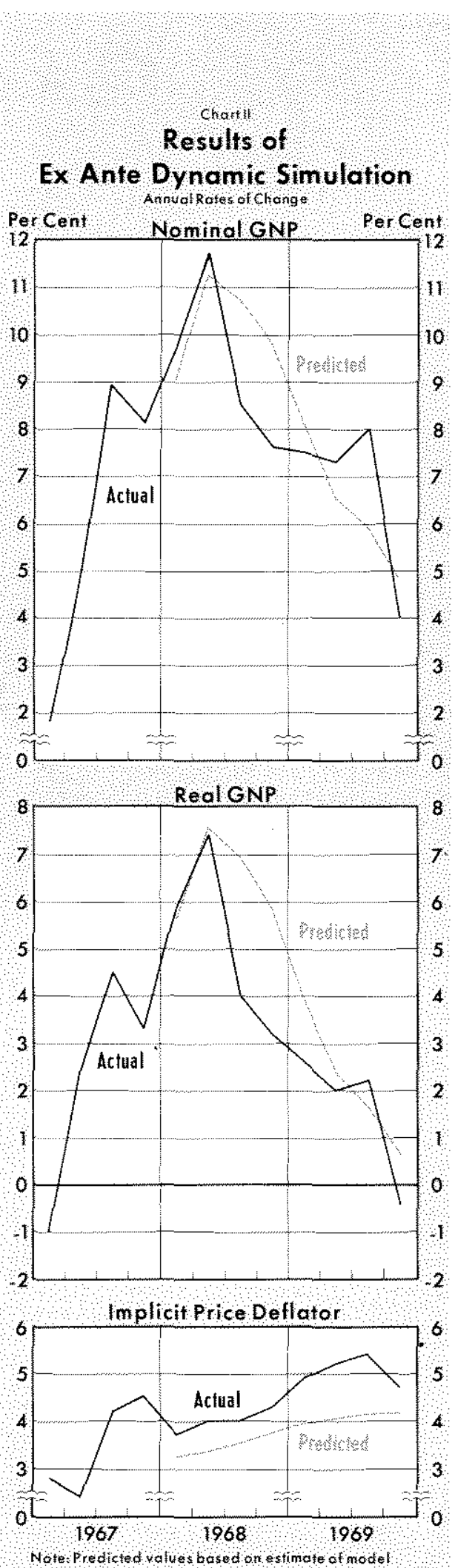

Nofedredised uques bosedonestimafe of model lor somple pefiodereding $\mathrm{Y} / 967$ 
Table $\mathrm{K}$

EX ANTE VS. EX POST SIMULATION. ACTUAI MINUS PREDICTED $1 / 1968$ V V/ 1969

(Roor Mean scuared Erors)

onpl

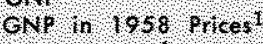

GNP Deflolor

Unemploynent role

Corporole $\mathrm{Aoc}$ Role

Connerdol poper role

\begin{tabular}{|c|c|}
\hline $6 \times 1801$ & $14 \mathrm{Ante}$ \\
\hline 128 & 1445 \\
\hline 099 & 15,8 \\
\hline 02 & 078 \\
\hline 014 & 020 \\
\hline 917 & 026 \\
\hline 0.44 & 1228 \\
\hline
\end{tabular}

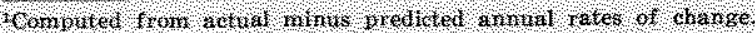

timating the economic response to monetary and fiscal actions. Unfortunately, it is difficult to conduct additional tests of this type for other subperiods in the sample, because degrees of freedom are severely reduced when the sample period is shortened further.

\section{Using the Model for Current Analysis}

The model is used in this section to simulate the effects of possible future rates of monetary expansion on spending, output, prices, unemployment and interest rates, given the economic circumstances of late 1969 and early 1970. Simulation of these altemative courses of monetary action suggests how the model may provide information which will be helpful to policymakers.
Simulations of the model are conducted only for alternative rates of monetary expansion. This is done because of the nature of the results for the spending equation. The net effect of a change in Federal expenditures on total spending (GNP) over a fivequarter period is very small if unaccompanied by monetary expansion.

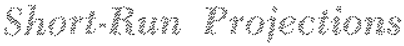

The results of simulating the model for alternative growth rates of money, and for the growth of Federal expenditures as projected in the fiscal 1971 budget, are shown in Table $X$. These simulation results reflect the accelerating inflation of the past several years and the fiscal and monetary restraint in force throughout 1969 and early 1970. These projections assume that empirical relationships based on past experience will continue to hold in the near future.

Rates of change in the money stock were computed from the first quarter of 1970 . Three alternative rates are shown in Table $\mathrm{X}$. The "no-change case" corresponds to the course of monetary actions in the second half of 1969 . The "three per cent case" corresponds to the trend rate of increase in money from 1961 to 1965 . Finally, the "six per cent case" represents monetary actions similar to those of 1967 and 1968 .

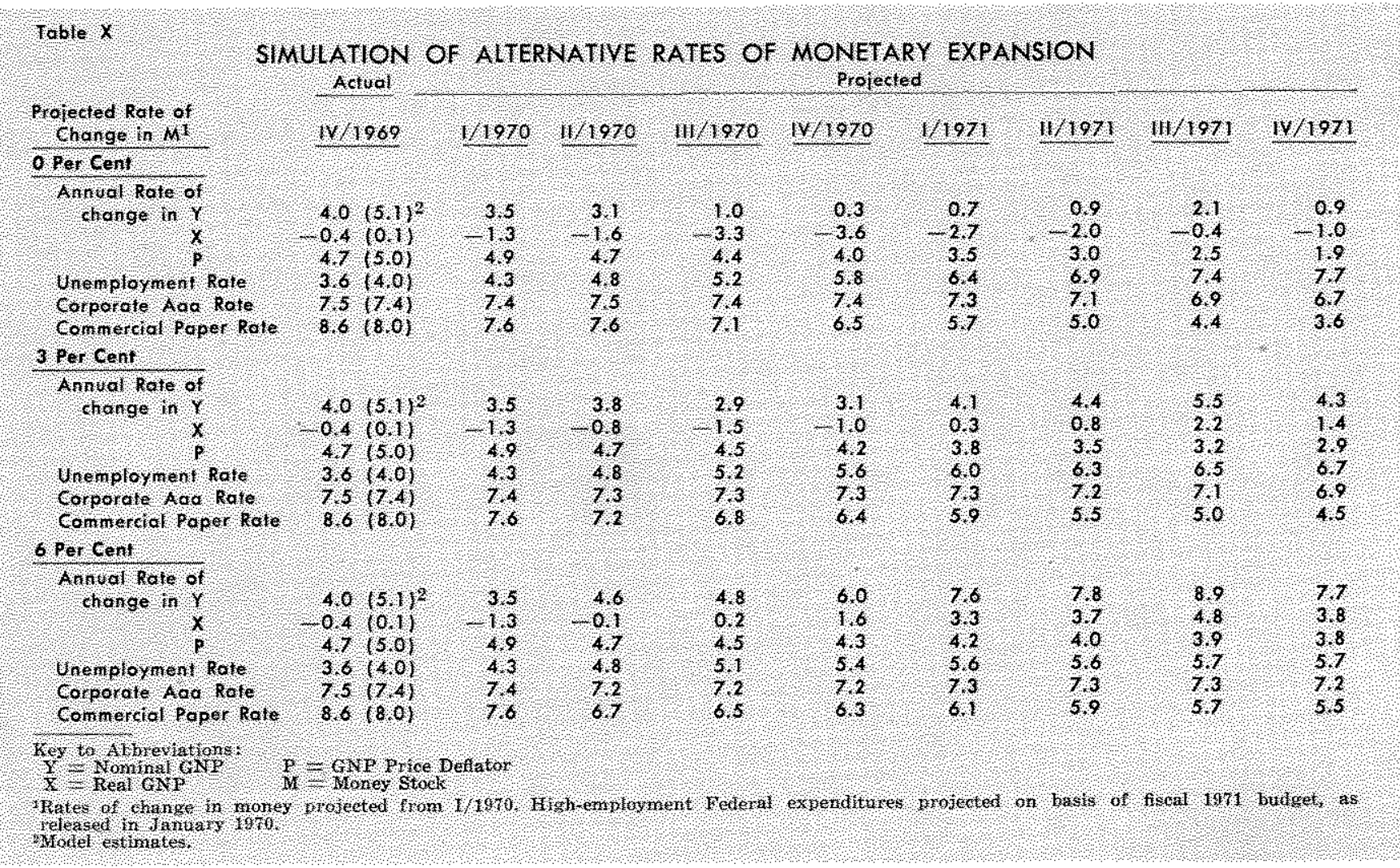


No-change case - A course of no change in the money stock from the first quarter of 1970 would lead to further reduction in the rate of increase of total spending in 1970 and 1971 (Table X). A slowing of total spending along with upward pressures on prices from the past inflation (anticipated price effect) would lead to continued declines in output through 1971. Such a restrictive course of monetary actions would slow the rate of price increase to a four per cent rate by late 1970 and to a two per cent rate by late 1971. The decline in output would be accompanied by a rise in the unemployment rate to over seven per cent by late 1971 .

The effects of such restrictive monetary actions on interest rates would be to keep the long-term interest rate at recent levels through 1970 , mainly because of the effects of past inflation. By early 1971, the slower advance of prices in 1970 and the slowing of output growth would lead to declines in the long. term rate. The short-term interest rate, on the other hand, would hold at recent levels only temporarily, partly because of continued restrictive monetary actions. Short-term rates would drop sharply by the second half of 1970 , reflecting primarily the slowing of output growth. Since the price lags are shorter for the short-term rate, the effects of past inflation are not so pervasive as for the long-term rate.

Three per cent case - Growth of the money stock at a three per cent annual rate is presented to illustrate the effects of a moderate expansion of money. This rate corresponds to the trend rate of increase in money from 1961 to 1965 . In the current economic situation, a three per cent rate of expansion in money would represent a moderate easing of monetary policy from its restrictive influence of late 1969 and early 1970.

The effect of such expansion would be to maintain growth in total spending at a rate about the same as in the fourth quarter of 1969. Given the influence of past inflation on prices, ontput would decline slightly through 1970, but would resume its increase by 1971 . The effect on prices in 1970 would be little different from the no-change case, but by late 1971 the difference would be marked. In the three per cent case prices would still be rising at a three per cent rate by late 1971 compared with a two per cent rate for the no-change case. Moderate expansion of the money stock leads to a rise in the unemployment rate through 1970 and 1971. In general, for this model, the unemployment rate rises as long as output grows at less than a four per cent rate.
The long-term interest rate would remain at recent levels throughout 1970, and not until early 1971 would the effect of slower price increases and output growth be enough to offset the effects of past inflation. The shortterm interest rate would fall more quickly than the long-term rate but would not fall as much by late 1971 as in the no-change case. Such a pattern for the short-term rate illustrates the shortand longer-run influence of quickened monetary expansion.

Six per cent case-A six per cent annual rate of increase in money is shown to illustrate the effects of a sudden shift to a very rapid rate of monetary expansion in the second quarter of 1970. Such increase in money would be about the same as during 1967 and 1968 .

A major effect of shifting to rapid monetary expansion would be to advance the rate of total spending growth. By late 1971, total spending would be increasing at an eight per cent rate with such monetary actions. The rate of price increase would fall somewhat, however, because of past restrictive monetary actions. But the gain in price performance would be small, because by late 1971 prices would still be increasing at a four per cent rate. The effects of past monetary and fiscal actions, along with past inflation, would lead to a decline in output through mid-1970. From then through 1971, output growth would increase.

Despite a shift to a very rapid rate of monetary growth, unemployment would rise until mid-1971. This increase in unemployment would follow because of the continued influence of past monetary and fiscal actions. By late 1971, the recovery in output growth would be pushing the unemployment rate back down.

A shift to rapid monetary expansion has a pronounced effect on market interest rates. The longterm rate would stay at recent levels through 1971, because the influence of past prices (anticipated price effect) would not be offset by a sustained reduction in output growth. The short-term rate would $\mathrm{fall}$, in response to the temporary reduction in output growth, but the decline by late 1971 would be less than for either the no-change or three per cent case.

\section{mulcatons of the Model for

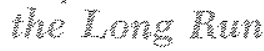

Short-run prospects for economic variables tend to dominate policymakers' decisions. However, the longer-run consequences of alternative monetary policies should also be given consideration. This model 
is incomplete for long-run analysis; nevertheless, it yields results that are of interest and may not be too far removed from results that might evolve from a more complete specification. ${ }^{31}$

When simulations are conducted for long periods into the future (thirty years), the model demonstrates properties consistent with those expounded by the classical economists. Over the long run, monetary actions have no effect on real magnitudes; the rate of growth of output, the unemployment rate, and the real rate of interest all tend to move toward some equilibrium rate, regardless of which rate of money growth is maintained. The effects of alternative rates of monetary expansion are on nominal magnitudes, namely, total spending, prices, and market interest rates.

Based on the assumptions of the model, a six per cent rate of growth in money along with a six per cent growth rate in Federal expenditures, for example, would lead ultimately to about a six per cent rate of growth in total spending, a four per cent rate of growth in output, a two per cent rate of increase in prices, and market interest rates about two percentage points in excess of the real rate. Alternatively, a two per cent growth rate in money would result approximately in a two per cent growth in total spending, a four per cent rate of growth in output, a two per cent rate of decline in prices, and market interest rates about two percentage points below the real rate. Over the long run, the model indicates that high employment and price stability are compatible.

\section{Summary}

The main purpose of this study has been to quantify the effects of monetary and fiscal actions

31The shortcomings of the rnodel for the long-run analysis are quite evident. There are no assumptions specified as to labor force growth and productivity. Furthermore, there is no investment function and, therefore, the capital stock is not an endogenous variable. All long run assumptions are embodied in assumptions about the growth rate of potential output. With these assumptions, policy actions cannot affect the economy's long-run growth rate. within a small-model framework and thereby offer an alternative to existing large-scale econometric models. Such a model has been formulated and the effects of monetary and fiscal actions on spending, output, prices, employment, and interest rates have been estimated.

The model developed in this article is primarily "monetarist" in character. The estimated equations indicate that monetary actions, as measured by changes in the money stock, play a strategic role. Fiscal actions, as measured by high-employment Federal expenditures, have some short-run effects, but for periods of a year or more the net effect on spending, output, and prices is near zero. Simulations of alternative rates of monetary expansion produce short-run and long-run responses which are consistent with the general monetarist view of the economy.

One of the chief advantages of this model is that it depends primarily on information about only two variables - the money stock and high-employment expenditures. ${ }^{32}$ Considerable insight can be gained about the pattern of expected movements of certain strategic economic variables by considering alternative courses of monetary and fiscal actions. However, since the model is limited to only monetary and fiscal influences, to the exclusion of other independent forces, it is not suitable for exact forecasting. ${ }^{33}$ Its primary purpose is to measure the general pattern of influence of monetary and fiscal actions on several strategic economic variables. Since the economy is viewed as being basically stable, other factors influencing total spending, output, and prices are not considered to be of great importance in estimating the response to monetary and fiscal actions.

\footnotetext{
32This feature has led John Deaver to conjecture that the standard error of forecast in the Andersen-Jordan model may be far lower than that of the FRB-MIT model. See his "Monetary Model Building," Business Economics, (September 1969), p. 30 .

${ }^{33}$ See Andersen and Jordan, pp. 15, 23, 24, and Leonall $C$. Andersen, "Money it Economic Forecasting," Business Economics, (September 1969), p. 17.
}

This article is available as Reprint No. 55.

The Appendices to this article begin on the next page. 


\section{APPENDIX A}

\section{EXPLANATION OF THE PRICE EQUATION}

The price equation (omitting timescripts and lags) is $\Delta \mathrm{P}=\mathrm{f}\left(\mathrm{D}, \Delta \mathrm{P}^{\mathrm{A}}\right)$,

where $D$, demand pressure, is defined as

$$
\mathrm{D}=\Delta \mathrm{Y}-\left(\mathrm{X}^{\mathrm{F}}-\mathrm{X}\right) \text {. }
$$

$\Delta Y^{*}$ is the change in total spending, $\left(\mathrm{X}^{\mathrm{F}}-\mathrm{X}\right)$ is the GNP gap, that is, the difference between potential and actual output, and $\Delta \mathrm{P}^{\mathrm{A}}$ is anticipated price change. This specification of the price equation is based on standard theory of macroeconomic equilibrium.

Macroeconomic equilibrium can be depicted graphically as in Figure I. The solid downward-sloping line, $\mathrm{X}_{\mathrm{Y}}^{\mathrm{D}}$, is the total spending line, which represents the combinations of prices and output consistent with a particular level of total spending, $\mathrm{Y}$. This total spending line can be interpreted as total demand for output.

\section{Figure I}

\section{Macroeconomic Equilibrium (Determination of Output and Prices)}

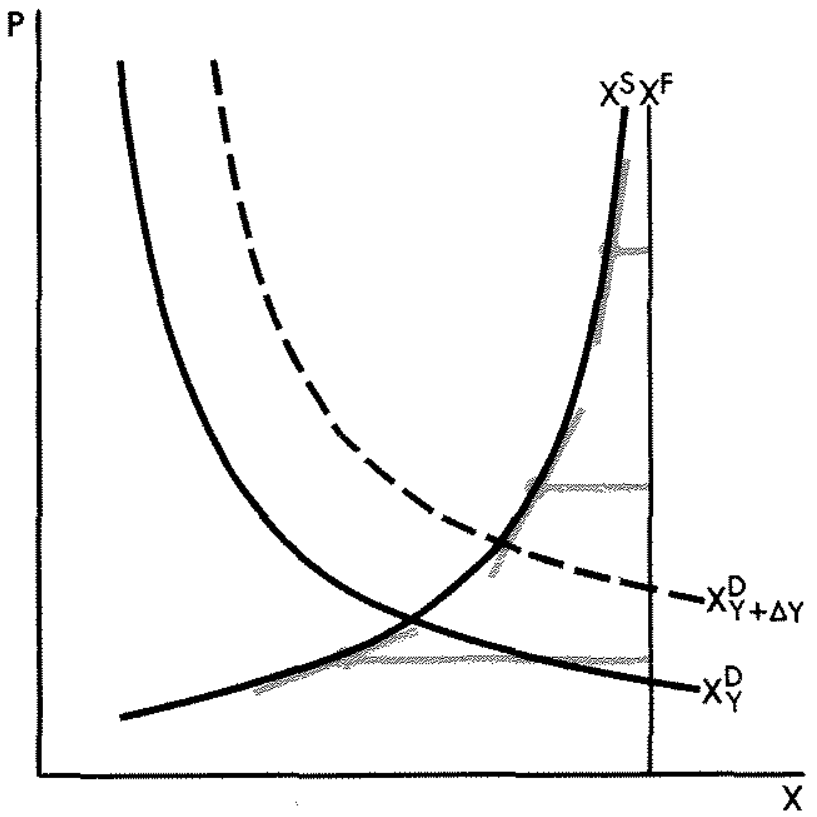

The upward-sloping line, labeled $\mathrm{X}^{\mathrm{s}}$, is the total supply line. This line cortesponds to that combination of prices and output which maximizes profits of firms, given the prices of factors of production, the degree of competition among firms and the stock of human and physical capital (defined to embody the state of technology).

The intersection of total supply and total demand determines the levels of output and prices. The equilibrium price level is that level which equates the amount of output supplied with the amount demanded.

The focus of the model is on the change in prices and the change in output. In terms of Figure I, changes in prices and output are brought about by shifts in demand and/or supply. Since $X_{Y}^{\mathrm{P}}$ is drawn for a level of total spending, a shift of that line upward and to the right to $\mathrm{X}_{\mathrm{Y}+\Delta \mathrm{Y}}^{\mathrm{D}}$ represents an increase in total spending. If the total supply line remains fixed, the effect of $\Delta \mathrm{Y}$ on prices depends on (1) the magnitude of $\Delta \mathrm{Y}$, and on (2) the slope of the total supply line, $X^{s}$.

The purpose of the model is to estimate the response of spending, output, and prices to monetary and fiscal actions, not to test a hypothesized structure. Consequently, rather than attempt to determine the shape of the total supply line empirically, its variable slope is proxied by the difference between potential output and actual output. As drawn in Figure 1 , there is a one-to-one relationship between $X^{1} \ldots X^{s}$ and the slope of $X^{*}$. Assuming that this relationship is approximately linear within the range of experience since 1955, and that the observed values fall on the supply line, the effect of a variable slope for $\mathrm{X}^{\mathrm{s}}$ can be approximated by $\mathrm{X}^{\mathrm{F}}-\mathrm{X}$. In this way the term $\left[\Delta Y-\left(X^{F}-X\right)\right]$ brings together both the magnitude of demand shift and the slope of the supply line.

The other term in the price equation, anticipated price change, $\Delta \mathrm{PA}^{\mathrm{A}}$, is considered as a separate influence on prices. In terms of Figure $I$, the anticipated price term is a shift parameter for the total supply line (an increase in $\Delta \mathrm{P}^{\Delta}$ shifts $\mathrm{X}^{\mathrm{s}}$ upward and to the left). Including it in this way allows for the influence of past prices on current pricing policies of firms and factors of production. 


\section{APPENDIX B}

\section{GRAPHICAL ILLUSTRATION OF THE MODEL}

The workings of the model can be demonstrated with graphical techniques. Figure $\mathbb{I}$ is a representation of the core of the model, showing the determination of changes in spending, output, and prices.

Panel A of Figure II is a graphical representation of the total spending equation with $\Delta \mathrm{M}$ on the horizontal axis and $\Delta Y$ on the vertical axis. Changes in $\Delta E$ shift the total spending line.

Panel $B$ shows prices $(\Delta \mathrm{P})$ as a function of $\Delta Y$. A short-run price line $\left(\Delta \mathrm{P}_{1}\right)$ is drawn consistent with empirical results showing that $\Delta \mathrm{P}$ is not very sensitive to $\Delta \mathrm{Y}$ in the short run. Important determinants of the position of the short-rum price line are the size of the GNP gap and anticipated price changes. The long-run price line $(\triangle \mathrm{P}(\mathrm{LR}))$ is drawn to show the relationship between $\triangle \mathrm{P}$ and $\Delta \mathrm{Y}$ when the GNP gap is zero and anticipated prices are equal to actual prices. Its slope (45 degrees

\section{Model in Graphical Form}

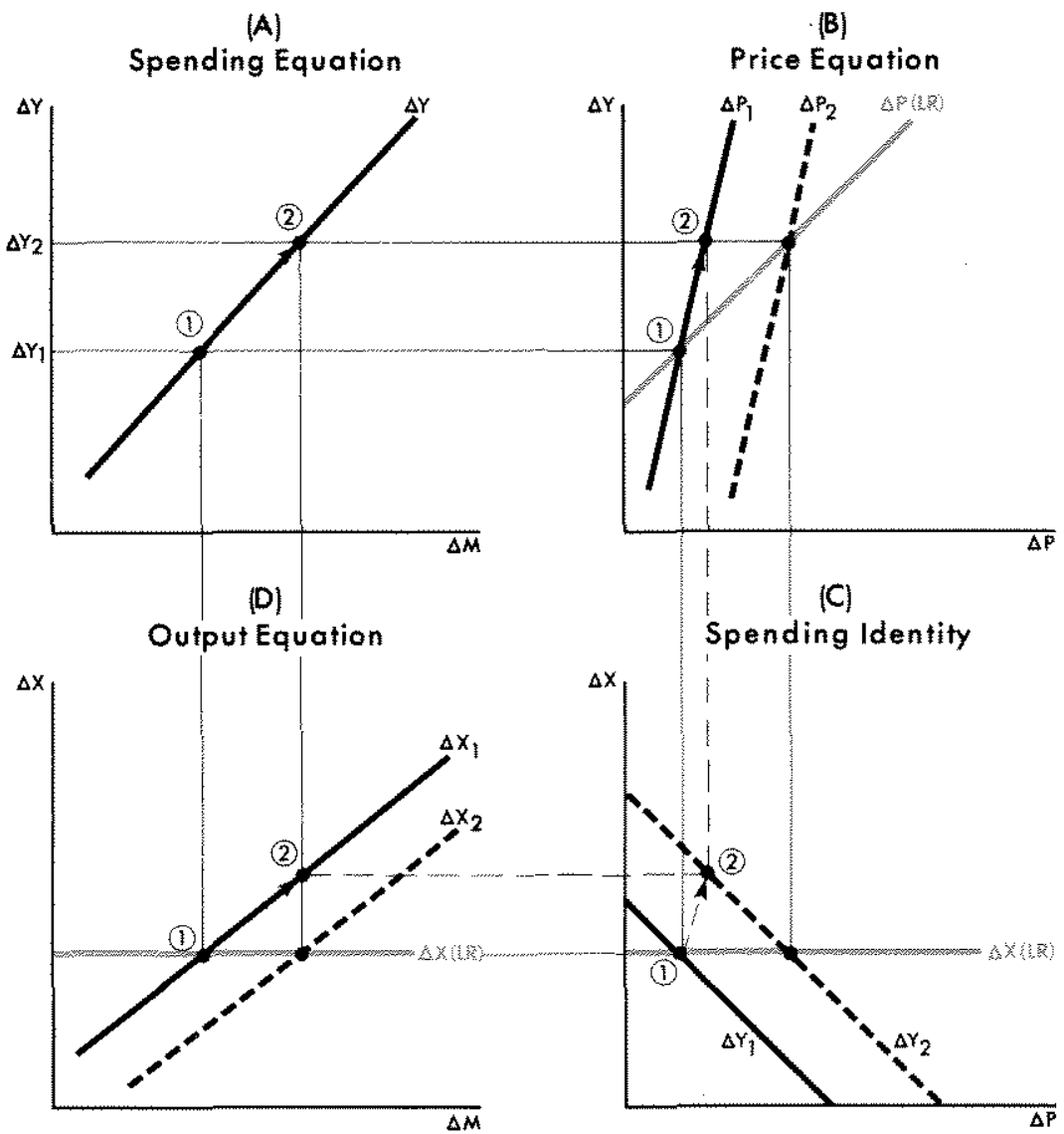

from its origin on the $\Delta Y$ axis is based on the monetarist view that in the long run, $\Delta \mathrm{M}$ influences only $\Delta \mathrm{P}$.

Panel $C$ expresses the total spending identity in graphical terms. Total spending is divided between output and prices; to reflect this, the line in panel $C$ is drawn as a 45 degree line with its position determined by the magnitude of total spending $(\Delta \mathrm{Y})$. There is a fatmily of 45 degree lines, one for each possible $\Delta \mathrm{Y}$. Also included in pariel $\mathrm{C}$ is a horizontal line representing the long-run growth rate of output. It is shown as a horizontal line to indicate that long-run output growth is exogenously determined by resource growth and technology.

In panel $\mathrm{D}$, the $\Delta X_{1}$ line shows the relationship between money $(\Delta M)$ and output $(\Delta X)$ as derived from the other three panels. The equation for this line is not shown in Exhibit $I$ in the text, but it can be derived from the other equations of the model.

Figure II is drawn to represent an initial equilibrium for a given $\Delta \mathrm{M}$, which has associated with it the shortrun price and output lines, $\Delta \mathrm{P}_{1}$ and $\Delta \mathrm{X}_{1}$. The effect of a change in $\Delta \mathrm{M}$, given $\Delta \mathrm{E}$, is shown as a movement along the spending line in panel $A$ from (1) to Given the initial price line, $\Delta \mathrm{P}_{1}$, and the changed $\Delta \mathrm{Y}$, the effect on prices and output is shown in panels $B, C$ and $D$ as a movement from (1) to 2 .

This case illustrates the impact of a change in $\Delta \mathrm{M}$ in the short run. For longer periods, anticipated price changes and the GNP gap will also change; they become endogenous variables in a long-run model. To illustrate the effects for the long run, the long-rum price line, $\Delta P(L R)$, in panel $B$, is relevant. The interpretation of the longrun price line is that changes in $\Delta M$ are reflected only in $\Delta \mathrm{P}$, with $\Delta \mathrm{X}$ determined by considerations of resource growth and technology. The horizontal line in panels $C$ and $D$ is the long-run relation between prices and output.

In the short-run, the solution of the model need not lie on the long run price line in panel $\mathrm{B}$ (or the long run output line in panels $C$ and D). However, a succession of short-runs (shown as a shift of the $\Delta \mathrm{P}$ and $\Delta \mathrm{X}$ lines to $\Delta \mathrm{P}_{3}$ and $\Delta \mathrm{X}_{2}$ ) will tend to move equilibrium toward the long-run price and output lines, as anticipated prices adjust to actual prices and the GNP gap goes to zero. 


\section{APPENDIX C}

\section{ALTERNATIVE PRICE EQUATIONS}

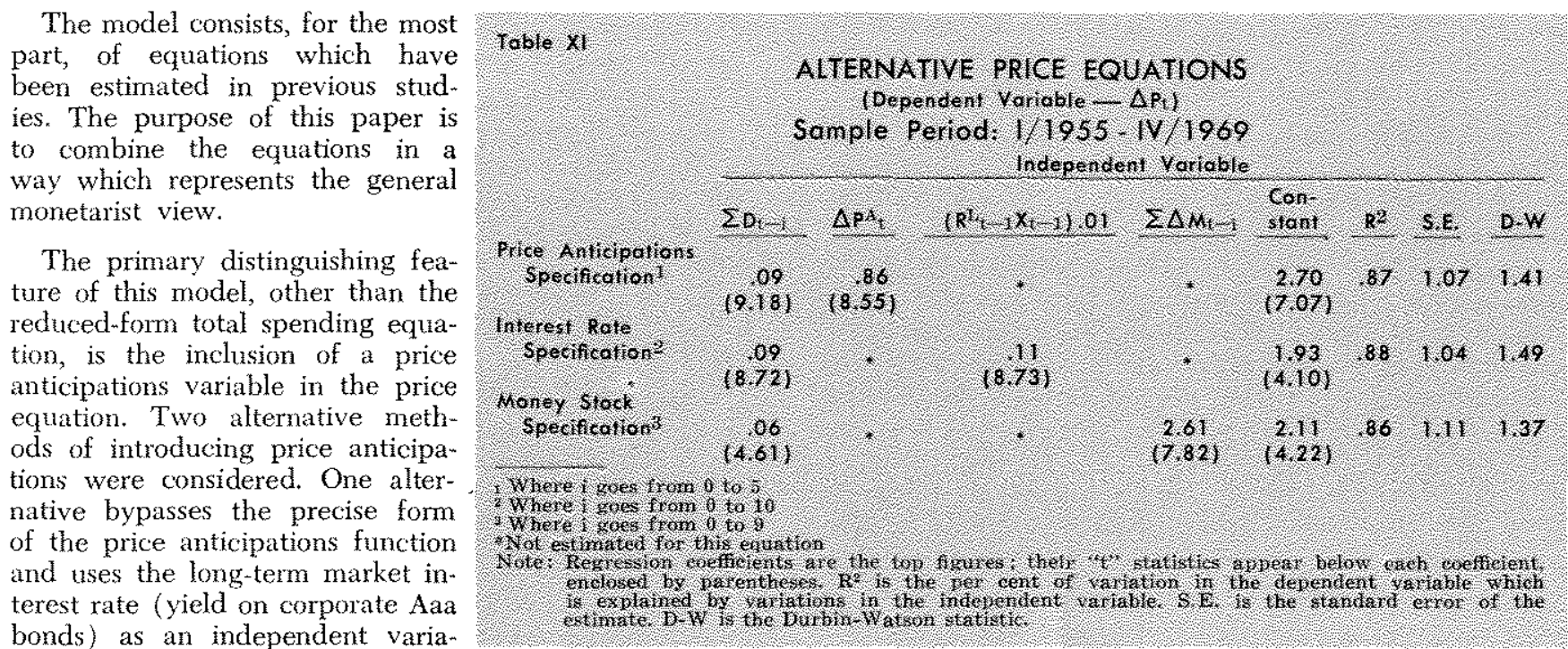

ble in the price equation. The

other alternative bypasses both price expectations and interest rates, and introluces changes in money as an independent variable in the price equation. Such a specification allows monetary actions to serve as a proxy for anticipated prices.

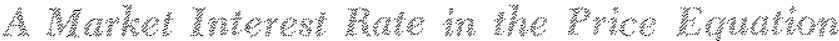

The first alternative replaces the price anticipations variable with the long-term market interest rate. ${ }^{1}$ The rationale is that the process of price anticipations formation is so complex that it defies measurement. However, there seems to be agreement that the level of market interest rates reflects anticipated price changes, how ever formed. Thus the market interest rate can be used as a proxy for price anticipations.

Since interest rates reflect factors other than price anticipations, inchuding the interest rate does not provide a clean measure of price anticipations. Using the market interest rate allows those factors influencing the real rate of interest to enter indirectly as an influence on prices. In general, however, it has been argued that the real rate of interest is very stable.

Following this reasoning, the price equation was estinated by including the long-term interest rate. The results are shown in Table XI. The coefficient of the interest rate variable is significant at the five per cent level for this specification, and the sum of the coefficients for the demand pressure variable is rouglly the

\footnotetext{
The suggestion for using the interest rate in the price equation came from the Morey and Banking Workshop at the University of Chicago.
}

same as for the price anticipations version of the equation. However, the length of the lag structure is longer, indicating that the response of prices to changes in demand pressure may be slower than in the basic equation. But this need not imply that prices are slower to respond to monetary actions, since the magnitude of the interest rate contribution to price change is smaller than with the price anticipations specification.

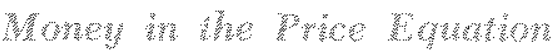

Several observers have been critical of price equations that do not include monetary variables directly. As shown in the text, excluding monetary variables from the price equation does not necessarily imply a nonmonetary theory of inflation.2 Such a conclusion cannot be derived by examining the price equation alone, but requires an examination of the whole model, and the linkages between money and prices in particular.

The second atemative that is considered is based on the central proposition of the quantity theory - that changes in money are ultimately reflected in changes in the price level. Accordingly, current and past changes in money are used as a proxy to measure anticipated movements in prices. ${ }^{3}$ Though this rationale for including money is somewhat narrower than that proposed by some monetary economists, the direct and indirect effects of money are being measured once it is included in the price equation.

"See Fand, "Some Issues in Monetary Economics," pp. 20-23. "This sugrestion was made by I'tofessors David Fand and Allan Melzzer. 
The price equation incorporating current and lagged values of changes in money is shown in Table XI. Except for the current quarter, the coefficients are significant for nine lagged quarters. The effect of including changes in money lowers the sum of the coefficients on the demand pressure variable, however. The overall explanatory power of the equation is about the same as for the price anticipations model.

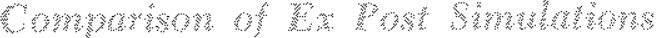

To compare the price equation in the text with the two altematives in this Appendix, the model was simulated with each of the three different specifications from 1965 through 1969 . The period starting in 1965 is used because the relative tracking ability of the models during a period of accelerating inflation is especially relevant in assessing the current economic situation. Since the price equation is the only part that varies from one model to the next, only the results for the rate of change of prices are reported. (see Table XII).

The price anticipations specification has the smallest average absolute error and the smallest root mean squared errot for the period. During the last two years of the period, 1968 and 1969, each of the alternative specifications tends to underestimate price changes. However, for 1968 and 1969, the price anticipations specification again has both the smallest average absolute error and root mean squared error.

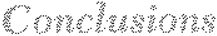

An examination of the model reflecting three different specifications for the price equation indicates that none of the specifications is clearly superior as judged by conventional criteria. A policymaker might well consider the results provided by each of the three.

When simulations are performed for thirty-year periods beginning in 1970 , the price anticipations version (as presented in the text) approaches closest a longrun classical solution. For the other two specifications the unemployment rate does not stabilize at the same

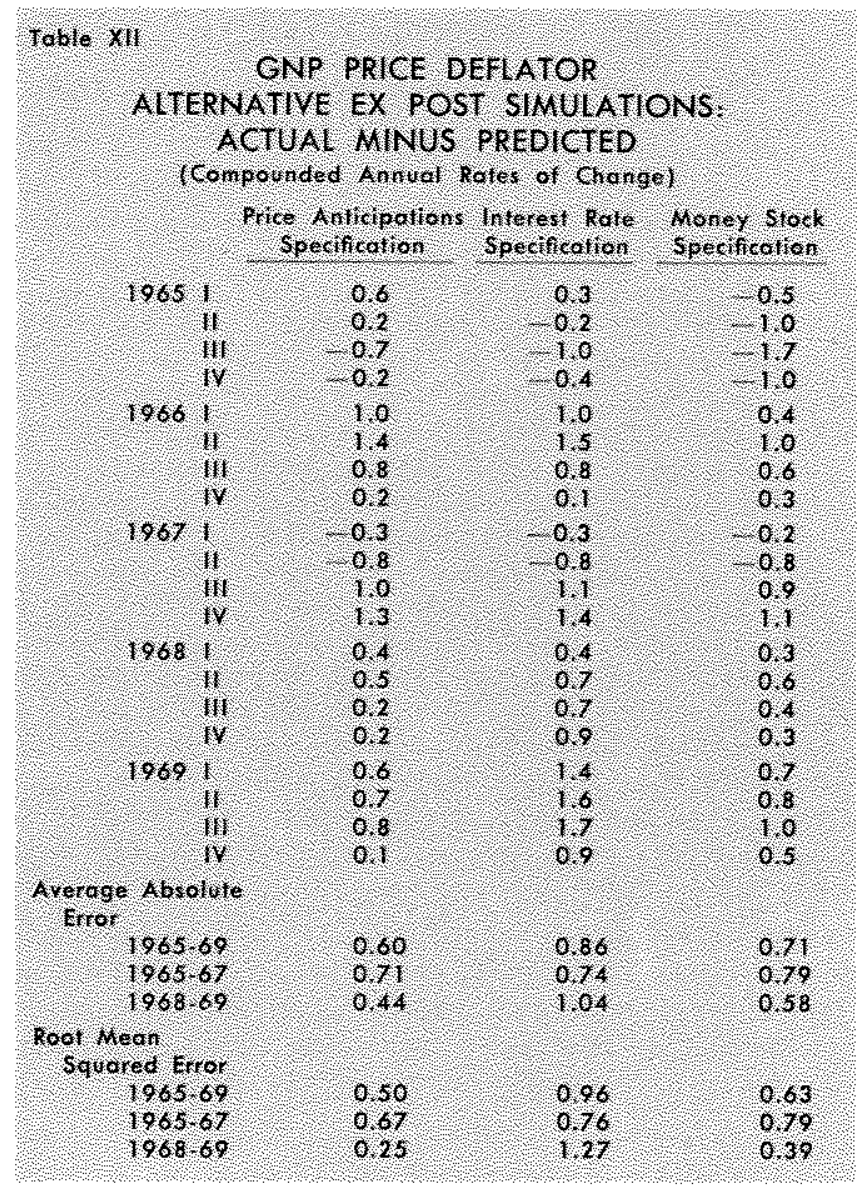

level for altemative growth rates of money. These two alternatives yield the same equilibrium growth rates of output for altemative growth rates of money, but since this rate is approached asymptotically, unemployment stabilizes at a different rate for each alternative growth rate of money. ${ }^{4}$

${ }^{4}$ Stupplementary materials relating primarily to the long-run simulations are available on request.

"Quarterly EcoNomic Summaky," a new release of this bank, will replace the quarterly "Triangles of U.S. Economic Data" next month, and is available to the public without charge, Based on the approach to stabilization analysis presented in this article, "Quarterly Economic Summary" will contain an outlook for Total Spending, Real Product, and Prices. It will include an explanation of the analysis, as well as charts and rates-of-change tables for national income accounts data and related series. Persons who have been receiving "Triangles of U.S. Economic Data" will automatically receive the new release. For subscriptions, write: Research Department, Federal Reserve Bank of St. Louis, P.O. Box 442, St. Louis, Missouri 63166. 